Florida International University FIU Digital Commons

$4-1983$

\title{
A study to identify the need for videotaped training material for civilian clubs
}

Terry Clark

Florida International University

DOI: $10.25148 /$ etd.FI14060846

Follow this and additional works at: https://digitalcommons.fiu.edu/etd

Part of the Hospitality Administration and Management Commons

\section{Recommended Citation}

Clark, Terry, "A study to identify the need for videotaped training material for civilian clubs" (1983). FIU Electronic Theses and Dissertations. 2372.

https://digitalcommons.fiu.edu/etd/2372 


\section{A STUDY TO IDENTIFY THE \\ NEED FOR VIDEOTAPED TRA INING \\ MATERIAL FOR CIVILIAN CLUBS}

by

TERRY CLARK

A hospitality project submitted in partial fulfillment of the requirements for the degree of MASTER OF SCIENCE

in

HOTEL AND FOOD SERVICE MANAGENENT

at

FLORIDA INTERNATIONAL UNIVERSITY

Committee in charge:

Professor Ted White

Doctor Donald Greenaway

April 1983 
To Doctor Donald Greenaway and Professor Ted White

This hospitality project, having been approved in respect to form and mechanical execution, is referred to you for judgment upon its substantial merit.

Dean Anthony G. Marshall

School of Hospitality Management

The hospitality project of Terry Clark is approved.

Professor Ted White

Doctor Donald Greenaway

Date of Review: 


\section{A BSTRACT}

A STUDY TO IDENTIFY THE NEED

FOR VIDEOTAPED TRAINING MATERIAL

FOR CIVILIAN CLUBS

by

Terry Clark

The purpose of this study is to determine if there is a need and a market for the production of video-taped employee training films specifically geared to subjects unique to club management. Data was collected by telephonic inquiries to the major commercial film houses affiliated with the production of hospitality training films, by inquiry with all nationally organized club management associations, and routine queries with professionals in the field on the subject matter. The hypothesis is upheld by the research and the study goes further to suggest an answer to this need by production of training films. 


\section{A CKNOWLEDGMENTS}

My sincere appreciation to the people listed below:

Professor Ted White - for his untiring enthusiasm, interest and expertise in completing the video tape.

Gene Marshall - for the idea that generated this project and related activities.

Don Sheehy - for his unending support to the project and to the student chapter of CMAA at Florida International University

South Florida Seminole Chapter, CMAA - for their continued support of the project and the student chapter, CMAA. Dean Tony Marshall - for his support of the student chapter, CMAA.

Student members, Sunblazer Student Chapter (FIU), for their willing responses to all requests and support of the project.

Cynthia - my lovely wife, who spent many days and nights alone, so I could accomplish the goals of CMAA and complete this project. 
TABLE OF CONTENTS

Section

Page

ABSTRACT ......................

ACKNOWLEDGMENTS ................ il

THE PROBLEM AND ITS SETTING ............. 1

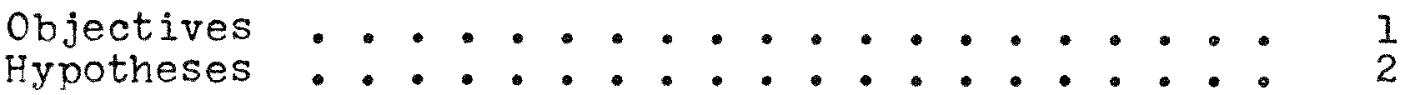

DEFINITION OF TERMS ................. 3

ASSUMPTIONS . . . . . . . . . .... 8

THE REVIEW OF THE REIATED MATERIAL . . . . . . . 10

ANALYSING OBJECTIVES AND RELATED RESULTS . . . . . 24

SUMMARY AND CONCLUSIONS ........... 34

APPENDICES • . . . . . . . . . . . 35

BIBLIOGRA PHY . . . . . . . . . . . . 36

VITA . . . . . . . . . . . . . 38 


\section{THE PROBLEM AND ITS SETTING}

This project hopes to show there is a need in civilian clubs for a broadly based selection of videotape training material, specifically, produced with club operations in mind, that managers can use in periodic employee training sessions to upgrade the overall efficiency and operation of the club.

\section{OBJECTIVES}

The first objective. The first objective is to determine what is available in the hospitality industry in the form of videotaped employee training material specifically geared to club management.

The second objective. The second objective is to use this special project as meritable contribution by student members of Club Managers Association of America in competition for the annually presented Student Chapter Achievement Award.

The third objective. The third objective is to create a mechanism to produce revenue for the Student Chapter at Florida International University in the form of selling a video cassette training film.

The fourth objective. The fourth objective is to encourage the national board of directors of Club Managers Association of America to endorse the concept of student chapters annually producing a videotaped training film that will, in turn, establish a film library dedicated solely to the management of clubs. 


\section{THE HYPOTHESES}

The first hypotheses is that a need exists for videotaped training material specifically produced for club operations that can be inexpensively produced by student chapters of Club Managers Association of America.

The second hypotheses is that the videotaped training films can be processed for orders, marketed and controlled by national headquarters of the Club Managers Association of America . 


\section{THE DEFINITION OF TERMS}

Club. A club is any gathering of selective, specific humans in a defined, delineated place for any social or recreational activity. 1

Club Managers Association of America (CMAA). The Club Managers Association of America is a non-profit membership organization composed of club managers representing over 3,000 private clubs throughout the world. 2

The objectives of the Association include:

1. To promote and advance friendly relations between and among persons connected with the management of clubs and other associations of similar character.

2. To encourage the education and advancement of its members.

3. To assist club officers and members through their managers, to secure the utmost in efficient and successful operation. gories: $\frac{\text { Clu }}{3}$

Club Managers Association of America Membership CateProvisional Member. A person who at the time of applying

1 Ted E. White, Club Operations and Management, CPI PubIishing Co. Inc., Boston, Mass., 1979, p. 2 .

21982-1983 CMAA Yearbook (Confidential Copy), CMAA Nat'l. HQ. Bethesda, Maryland 20817, p. 18.

3 Ibid., p. 35. 
for and election to membership in the Association, and is employed as an executive, manager, or assistant manager of an entity defined as a private membership club.

Active Member. A dues paying club connected member entitled to hold office and take part in all business affairs of the Association.

Associate Member. An associate member is a disengaged active member that retains the entitlement of membership without the right to vote or hold office until the time he reengages in a position of club management.

Student Member. An individual who is enrolled in a hospitality course of instruction in an accredited college, university or school for undergraduate or graduate students. Such membership does not entitle the holder to vote or hold office in the Association.

Retired Member. Active or associate member who is at least sixty-five years old who has been a member of the Association for an aggregate period of fifteen years.

Honorary Member. Any individual who has rendered special service of value for the promotion and advancement of the welfare of the Association.

Surviving Spouse Member. A membership status afforded surviving spouses of a CMAA member that entitles member social privileges, publications, newsletters and magazines. CMAA Student Chapter. ${ }^{4}$ A dues paying membership non-

41983 CMAA Student Chapter Handbook, (CMAA National HQ, Bethesda, Maryland), p. 6 . 
profit association located at an accredited college, university or school hosting courses in hospitality management. Objectives of the student Association are to:

1. Inform college and university students about club management as a profession, to make them aware of the career opportunities in club management and to serve as the liaison between the practicing professionals and the academic community.

2. To provide students with employment opportunities within the club industry by means of part-time employment during the academic year, through opportunities for summer employment, work-study internships, and by placement guidance upon graduation. 5

All student chapters are required to have a CMAA liaison manager and faculty advisor.

CMAA Liaison Manager. 6 An active CMAA member who acts as an advisor and works with student chapter, faculty members, and the local CMAA chapter.

Club Management Institute. 7 The Club Management Institute is the official educational section of CMAA, managed by the

51983 CMAA Student Chapter Handbook, op. cit., p. 13.

6 Ibid., p. 12 .

71982-1983 Yearbook, op. cit., p. 48. 
Institute Committee (five active members of the Association appointed by the Association President) to develop and maintain a program of education in which the most advanced principles and precepts of professional club management will be available at all times to those who are employed in the club management field, and to universities which offer club management as a regular or special course of study for students who desire training in the subject.

Mid-Management Referral Service. 8 A monthly listing, published by the National office and received by officers of each chapter, containing names and qualifications of applicants interested in securing positions at a club as assistant manager, maitre'd or food and beverage assistant. Student Development Committee. ${ }^{9}$ A committee of active club members whose scope it is to develop, promote and execute programs to make students attending hospitality schools aware of CMAA and the opportunities available within the club management profession.

Student Chapter Achievement Program. 10 The chapter achievement program is one of recognition by CMAA for outstanding work and successful accomplishments by the student chapters within the Association. Areas of judging include:

\section{${ }^{8} 1983$ CMAA Student Chapter Handbook, op. cit., .p. 16. 91982-1983 Yearbook, op. cit., p. 10.}

101983 CMAA Student Chapter Handbook, op. cit., p. 14. 
(1) Educational Programs; (2) Membership Growth; (3) CMAA Involvement and Published Articles; (4) Employment in Clubs; (5) Special Projects. The first student chapter achievement award will be presented for the school year 1982-1983.

Information, Research and Publications Committee (IRP Committee).11 The IRP Committee composed of active members whose scope it is to evaluate the need for compiling professional and industry data through Association surveys and other means. Also, general responsibility for and supervision of external publications of CMAA and the responsibility of advising the Board of Directors of procedures that would make such publications effective and useful. 


\section{ASSUMPTIONS}

\section{ASSUMPTIONS:}

The first assumption. The first assumption is there is a need in the private club management profession for training material, other than textbooks and other printed matter, to allow managers to conduct periodic employee training sessions. The second assumption. The second assumption is that student chapters throughout the United States will have the resources to produce subsequent training videotapes.

THE IMPORTANCE OF THIS STUDY

Outside of govermmental agencies, there is currently no production of audio visual aids available in commercial or association libraries that covers specifically the subject of hospitality management in private country clubs. Many of the member demands common to the club operations do not exist in the hotel, airline, resort or restaurant operations. These unique methods of operation are not commonly appreciated by hourly-waged employees and are slowly learned through perseverence and experience in the club. Employees who may be apprised of the unique methods of club operations through the exposure to this training material may allow them the opportunity to adjust more rapidly and be a better employee of the clab.

If accepted for further development, this project will be a precedent setting step forward in furthering the educa- 
tion and development of club employees, thus enhancing the quality of service club members expect, and exemplifying the professional manner in which employees meet the members wants, needs, desires and expectations.

The precedent setting method of educational programs will illustrate once again the Club Managers Association of America's dedication to their objective to provide education to persons connected with the management of clubs and to promote and encourage efficient and successful club management.

If accepted for further development, the project will serve as a vehicle to educate student members through the annual production of subsequent training films on varied subjects unique to the operation of clubs. 


\section{THE REVIEW}

OF THE RELATED LITERATURE

\section{A Historical Overwiew}

Training of "tavern" employees has always been an area requiring attention. The hospitality industry, borne from the family operated taverns has changed significantly throughout the years. The model tavern was operated by the family nucleus with the father being overall manager, the mother or daughter in the kitchen, and other family members attending to the details of service. Outside the family resources would come the hard labor in the maintenance and upkeep of the tavern. 12

Skills were basic and training was passed on from older members of the family to younger members.

The introduction of new equipment, machinery and an interest in nutrition and sanitation in the late 1800 s changed the conceptual framework of the hospitality industry and made formal training a necessity. ${ }^{13}$ At this point taverns changed to hotel and restaurant operations. The method of most of the training in the hospitality industry then and even recently is expressed in the following excerpt:

12Donald E. Lundberg; James P. Armatas, The Management of People in Hotels, Restaurants and Clubs, 3d Edition; (Wm. C. Brown Co. Pub., Dubuque, Iowa, 1974), p. 66.

13 Ibid. 


\begin{abstract}
Your dilemma is shared by many: desperate for help, you grab the first warm body of (sic) the street and put him/her to work washing dishes, bussing or waiting tables, greeting guests, mixing drinks, doing God only knows what.... in a business where the ratio between customer and customee (that's you and your swill (sic) help) is as close to one-to-one as you can get outside of a message parlor and ought to be-in many instances-as intimate; and then, when your profits start to drop off and when your employee turnover becomes so great you've decided (and rightly so) to replace your service entrance with a revolving (sic) door, you wonder how it all happened and decide, like your pal (sic) down the street who just happens to be contemplating another wholesale revision of his/her menu and the prices thereon, to blame the recession. 14
\end{abstract}

In the midale of the I900s the U.S. Government, with the Department of Labor, recognized a void in the training of personnel in the food service industries and spent 100 million dollars to expand and speed up training employees in the hotel and restaurant industry. 15 This coincided with the greatest boom of the industry during and following World war II. Hospitality training programs throughout the United States developed in a large number of high schools, community

${ }^{14}$ Author Unknown, "Training: The only way to Fly," Hospitality, July 1975, p. R38.

15Lundberg and Armatas, op. cit., p. 157. 
colleges and vocational schools in the past 50 years. Along: with these increased educational opportunities, such great institutions as the Culinary Institute of America are producing some of the best skilled and qualified work force for the industry than ever before.

With the tremendous growth of the fast food restaurants, chain hotel and restaurants and management contract operations in the past thirty years, much time and money in the personnel departments has been expended to formalize the training techniques of employees. Development of policy and procedure manuals, job descriptions, task analysis, orientations and testing has become commonplace with some of the leaders in the industry. This, too, is necessary because of the sophisticated equipment and the scientific approach to operations that has come with this equipment. Layout and design of facilities have been geared to accept a particular performance level of the employee and every effort is made by designers to make efficiency in operation high and errorless as much as possible.

Basics of Training

Many managers know what they expect from employees but do not communicate this need either through praise, constructive criticism, training or testing.

With a good training program the club can achieve many benefits, among them are: 
(1) Increased Learning Rate

(2) Increased Quality of Performance

(3) Decreased Breakage and Spoilage

(4) Reduced Number of Accidents

(5) Reduced Labor Turnover

(6) Reduced Absenteeism

(7) Increased Production

Among these the most obvious outcome of training is increased productivity (and that means profits) which should result for the employee increased earning power, prepare them better for advancement and give them an increased feeling of security and economic independence.

Donald Lundberg and James Armatas express this in form of an equation:

$$
\begin{aligned}
& P=\text { COMPETENCE } \times \text { MOTIVATION } \\
& P=\text { Performance } \\
& P=\text { Proficiency } \\
& P=\text { Proficiency } \\
& P=\text { Productivity } \\
& P=\text { Knowledge } \\
& P=\text { Profit }
\end{aligned}
$$

Competence implies knowledge, education and particularly training. They continue to add that training consists of a 4-step job instruction method: 
(1) Prepare the learner - place in proper position

(2) Demonstrate the operation

(3) Have the person do the job

(4) Follow-up

Other methods of instruction may include:

(1) Orientation lecture and tours

(2) Sponsor training

(3) Role Playing and skits

(4) Problen situation and skits

On the orientation and sponsor training methods, the following is excerpted from Hospitality, July 1975 article:

One of the most important things in training is indoctrination of the people when they first come to you. The majority of the employee turnover happens the first day, the first week. It is simply because the fellow just doesn't feel like he's really been accepted in his first day, his first week。

"I always tell people to think back to the first day they were on a job in food service. You couldn't even go to the restrooms because nobody told you where it was. And you didn't know what to eat or where to eat. At the end of the week, everybody got paid and you didn't. You thought they'd forgotten you." 16

16 Jack Miller, "Training," Hospitality, July 1975, p. R38. 
Segment of the Market - Clubs

Very little written material has been published on the training of personnel in the civilian clubs. Membership associations such as Club Managers of America and Club Managers Association of America have, as their foundation, educational programs, but these programs and seminars are geared primarily to the management level of education. However, Club Managers Association of America does offer written training materials and films on the following subjects:

Food Preparation

Cive Your Eggs a Break The Hamburger Sandwich

A Cool Head for Salads

Fast Sandwich Making

Preventing Waste

Vepetable Preparation

Food Service

Food Service is People Service

Taking the Order

$\mathrm{Mr}$. Bus Boy

Selling Wine and Liquor

Sanitation

Why All the Fuss?

Rules Make Sense

Management

Eye of the Supervisor

Motivating Through Insight

Flight Plan

Delepate--Don't A bdicate

The Time Machine

The Manager and the Law

It is apparent here that areas of concentration are on 
the preparation of foods and management and many more key skilled and unskilled functions within the club could be explored through education.

A fact finding search of related material does bring to light inspiring highlights of training in clubs. In two unrelated articles, five years apart, the name of Jack Miller appears as a leader in the field of club management training. Professor Miller was an associate professor in the Department of Hotel, Restaurant and Institutional Technology at Community College of St. Louis, Forest Park Campus, and later became Chairman of the department. He states his philosophy of employee training:

The critical thing in your (manager's)
career planning--what you are doing
10, 15 or 20 years from now--depends
on how well you are doing your job
right now. The people who work for
you will iet you succeed to the
degree they want you to succed.
If they are going to help you, you
are going to have to help them by
training them, by giving them the
tools to do their jobs. I know you
don't have the time, but somehow you're
going to have to go in and give on-the-
job training under a systematic pro-
gram.I?

Professor Miller was a former club employee and restaurant manager prior to his activities with the community college. He has also made many contributions of time and talent to the National Restaurant Association. The key to his philosophy is

17Eldon Miller, "Training Program? You're Kidding!," Club Management, December 1976, pp. 16-18. 
the systematic on-the-job training program. He stated that such a program would consist of:
(1) A training budget
(2) Qualified instructors
(3) Demonstrations
(4) Audio/visual aides

And the essential ingredient is for management participation in the training. "Actually get in the trenches and show your employees how the job is done. It will be tough; it will be time-consuming. But in the long mun, it should pay in improved staff performance and club operations."18

Jack Miller and several associates from the Community College were featured speakers at a regional Club Managers of America meeting where the emphasis was on employee training. Some managers, especially those of smaller clubs, openly questioned the value of training. Their complaints ranged from low pay, small number of employees, satisfied membership with what they have in employees.

Even after several hours of seminar, reluctance existed on the part of these professional club managers to a need for a systemmatic program of training for "their" clubs.

The U.S. Army goes a long way to formally educate and train the club managers. They also, in the past ten years, have developed many training aids such as training briefs for 
employee training at each site, to be taught by managers. These training briefs are inexpensively reproduced and can be given to the employee for observance during the training session and later for reference. Over 100 training briefs include such specific subjects such as:

Security of Your Assets

Food Preparation

Standardized Recipes

Risk Management
Beverage Control

Food Spices and Garnished

Bingo Operations

Monte Carlo Gaming Nights

Other training aids come in the form of film, either $16 \mathrm{~mm}$ or $3 / 4 "$ video tape that are produced by the U.S. Army Club and Community Activities Management Directorate in Washington (the main staff agency for overview of club operations). These presentations are very professionally produced on specific subjects and are supplemented by training briefs and a short examination. Examples of what is available in audio-visual aids for the employee training program are listed below: ${ }^{19}$

\section{BEVERAGE CONTROIS}

$$
\begin{aligned}
& S F-20-564 \\
& S F-20-565 \\
& S F-20-566
\end{aligned}
$$

Cash Controls

Inventory Controls

Sales Accountability Controls

19Author Unknown, "Films and Videotapes," Army Host, September/October 1981, p. 6 . 


\section{FOOD MANAGEMENT}

Marketing, Menu Item Development and Merchandising

Product Development and Specifications

Food Purchasing

Receiving, Storing and Issuing

Food Production

Food Controls

Service and Sales Accountability

\section{OTHER FILMS AVA ILABLE}

Receiving Meats

Napoleon and The Empress Recipe

Mexican Extravaganza (How to Do a Promotion)

Improved Technology

Tremendous advancement in technology has improved the quality of video presentations in the past forty years. From $32 \mathrm{~mm}$ camera cimetography to the present $1 / 2$ " video cassette television systems are benefits to the user. ${ }^{20}$ In the past ten years technological improvements in the quality of equipment including cameras and players, have made the television receiver the most accepted, preferred and economical method of producing and using video presentations. Major movie producing companies, television broadcasting companies, and other commercial film makers are converting $16 \mathrm{~mm}$ film or $3 / 4^{\prime \prime}$ video tape to the $1 / 2$ " Video Home System (VHS) or BETA format to make it

\section{0 "How to Make Smart Video Connections," Pamphlet by} Xantech Corporation, 1982, p. 1 . 
available to the user who can economically purchase a video recorder/player and use it in a variety of uses. These video recorders/players can be purchased for as little as $\$ 250$ and have the capability to record from the television, or play pre-recorded video tapes on a variety of receivers ranging from five inches to six feet in area covered.

Higher cost of video recorders/players depends on the additional capabilities the purchaser may desire on the machine. This method of viewing video presentations is predicted to be the best method for years to come because of the capability of the system, the economical purchasing price of the equipment and materials associated with the production, and the end user acceptance to the product.

\section{Commercially Produced Training Films}

The leader in commercially produced training films in the food preparation and service areas is National Educational Media, Incorporated, located in Chatsworth, California. 21 Institutions, businesses, schools, and military and governmental agencies in 100 countries use these films to set higher standards of job performance while helping employees to achieve those standards. 22 They also cover such subjects as professional management, communications and selling, cashiering and security,

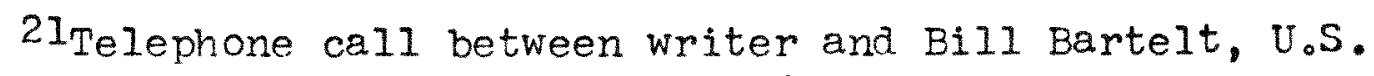
A rmy Club, Washington, D.C., April 1983.

Inc., p. 1 .
${ }^{22}$ NEM Inc., 1982 Catalog, National Educational Media, 
hotel and tourism, and public health. A listing of film titles available for rent or purchase in the professional Food Preparation and Service Series include: 23

FOOD PREPARATION
(1) Deep Fat Frying
(10) Braising and Stewing
(2) Give Your Eggs A Break
(11) Vepetable Preparation
(3) Carving the Rib Roast
(12) Simmering and Poaching
(4) The Hamburger Sandwich
(13) Short Order Cookery
(5) Broiling
(14) The Microwave Oven
(6) A Cool Head for Salads
(15) Sauteing and Pan Frying
(7) Sandwich Preparation and Presentation
(16) Soup Preparation
(17) Preparing Stocks
(8) Fast Sandwich Making
(18) Kitchen Knives:
(9) Roasting Safe and Efficient Use

INTERNAL CONTROLS

(1) Portion Control: A Team Effort

(2) Preventing Waste

(3) Using Standardized Recipes

(4) Receiving and Storing

(5) Food Purchasing I: General Principles

(6) Food Purchasing II: Let the Buyer Beware

(7) Bar Management: Internal Controls

FOOD SERVICE

(1) Courtesy: Food Service is People Service

(2) Courtesy: The Inside Story 
FOOD SERVICE-cont.

(3) How Do You Look When it Counts?

(4) Taking the Order

(5) Presentation of Food and Beverage

(6) Table Settings

(7) Bussing

(8) Rush Hour Service

(9) Cafeteria Service

(10) Hosting

(II) Banquet Service

(12) Buffet Layout and Service

(13) The Efficient Bus Person-Assisting the Server

BEVERAGE SERVICE

(1) Selling Wine and Liquor

(2) Bartending

(3) Bar Management: Internal Controls

(4) Hand Washing of Kitchen Utensils and Glassware

SA FETY

(1) Kitchen Safety: Preventing Falls

(2) Kitchen Safety: Preventing Burns

(3) Kitchen Safety: Preventing Machine Injuries

(4) Kitchen Safety: Preventing Cuts and Strains

(5) Kitchen Safety: Preventing Fires

(6) Care and Cleaning of Kitchen Equipment

(7) Dining Room Safety 


\section{SANITATION/HYGIENE AND PUBLIC HEALTH}

(I) Dish Machine Operator

(2) Sanitation and Hygience: Why the Importance?

(3) Sanitation and Hygiene: Basic Rules

(4) Dining Room Sanitation

(5) Sanitation: Rodent and Insect Control

(6) Personal Grooming and Hygiene

Each of these film presentations are available in the following formats: 24

(1) Standard $16 \mathrm{~mm}$ color/sound film

(2) 3/4" V-Matic and 1/2" Betamax and VHS video-cassettes

(3) Super-8mm Automatic Cartridge System

In addition to the film product, these films are supplemented with student study guides, discussion leader's guide, and an instructors guide. This instructional material rents for approximately $\$ 70$ each, per week, or can be purchased for approximately $\$ 300$ average per subject of instruction. 


\section{ANALYSIS OF THE OBJECTIVES}

\section{AND RELATED RESULTS}

Objective one. The first objective is to determine what is avalable in the hospitality industry in the form of video taped employee training material specifically geared to club management.

Telephonic inquiries to headquarters of the National Restaurant Association, International Military Club Executives Association, Club Managers Association of America, National Educational Media, Inc., Continental Film Products Corporation and the U.S. Army Club and Community Activities Directorate, plus library search within film libraries, have resulted in the identical answer to this subproblem. There is no company currently in existence that is producing videotaped employee training films outside of governmental agencies. The U.S. Army has discontinued duplication of their food and beverage management videotaped series because many of the systems and procedures depicted in the film have become obsolete. 25 This training material has been replaced by food and beverage technical manuals. The U.S. Air Force Club Systems are continuing to use video-taped presentations to teach and test skills of employees. The U.S. Army spokesman commented that the films certainly filled a void in education during that period, but there are no short or long term plans to produce any farther 
video-taped training material. They have tasked individual unit managers to implement a periodic training program on a regularly scheduled basis covering many subjects unique to club operations. This training schedule is supplemented with written material for the instructor and employee.

The second objective. The second objective is to use this special project as a meritable contribution by student members of CMAA in competition for the annually presented Student Chapter Achievement Award.

The criteria for selecting one of 17 active student chapters for presentation of the Annual Student Chapter Achievement Award was created by the student development committee, agreed upon by officers of each student chapter, liaison manager and faculty advisor, and approved by the CMAA National Board of Directors for implementation effective the 1982-1983 School Year. 26 A tentatively completed (period mus through June 1983; however, our Spring semester concludes April 22, 1983) entry summary is included as Appendix A. This entry will be examined by the Student Development Committee of CMAA. The committee will present a traveling trophy award to the chapter selected as the winner with a miniature trophy to be kept by the winning chapter. The first winners for school year 19821983 will be properly recognized at the 1984 CMAA National Convention to be held at the Opryland Hotel, Nashville; Tennessee,

26"The Chapter Achievement Award for Student Chapters," CMAA Pamphlet, 1982-1983, p. 1 . 
during the period February 12-14, 1984.

The third objective. The third objective is to create a mechanism to produce revenue for the student chapter at florida International University in the form of selling a videotaped cassette training film. This objective was reached with the production of such a film that was made available for marketing and is on file with the FIU Media Center. Outline of objective completion follows.

\section{Purposes}

(1) To create a professionally produced, high quality, color, videotaped training film. The subject of the film will be unique to the club management field and the quality will be such as to attract the desire of CMAA members to purchase the film for use in employee training sessions at their clubs.

(2) To develop a vehicle with revenue producing capability to offset expenses for student travel and lodging to local, regional, and national CMAA conferences.

Background

In June of 1982, Gene Marshall, a director of the South Florida Seminole Chapter, approached four members of the Sunblazer Student Chapter (FIU) with an idea to produce a 
training film as an entry into the annual idea fair contest sponsored by CMAA. This was to be a cooperative project with a dual purpose of the idea fair contest for the Seminole Chapter submission and a revenue generating project for the student Chapter. A chronology of events leading up to the actual production of the film follows:

Sentember 3, 1982: A steering committee meeting was held at Florida International University between four student members, four Seminole Chapter Members and the faculty advisor, Ted White. Gene Marshall indicated the Seminole Board had approved $\$ 500$ to offset initial expenses of the film that would be returned to the Seminole Chapter if sales generated sufficient revenue. Ted White stated that the School of Hospitality Management had agreed to the project and the University's film media department would support the production of the film. Ted White was selected as director and script writer for the project and he discussed six major areas of concern:

(1) Script - The script should focus on Country Club service. One table of four guests will be served French style service and the other four guest table will be served "American Club style Service."

(2) Location - Don Sheehy, Liaison Manager for the Sunblazer Student Chapter (FIU) and General Manaper, Westview Country Club, offered his facility, food, and personnel for the project. 
(3) Finances - Financing will be required for payment of transportation, labor materials and professional editing of the film. The suggested price of the film will be discussed later.

(4) Personnel - A mixture of students and Seminole Chapter Members will be used for the eight guest acting roles. Support personnel for the shooting of the film will come from the Sunblazer Student Chapter.

(5) Releases - Copyrighting of material will require some investigation.

September 7, 1982: At this meeting Ted White introduced a brief script and provided it to the group for comments and rapid return to him for completion. Major atcome of this meeting was the title, "Your Club: It Serves You Right," as recommended by John Gerecter, Seminole Chapter Member. Length of the film was agreed upon as 10-15 minutes.

October 13,1982: At this meeting Ted White provided an updated script which included camera angles, audio, camera field, time spans and a prop list. It became apparent at this meeting that a great deal of expertise, other than club management skills, in the field of movie production was needed to produce any type of $\mathrm{film}$. The steering committee reitterated their gratitude to Ted White for his talent in this area and 
the dedication he was demonstrating during the project meeting. Professional narration was agreed upon by the committee. Development of music score to accompany the film must be accomplished. Dress of guest actors and employees was determined. Final decisions were made by the committee on the menu. Suggested selling price of the finished production was still pending.

November 3, 1982: At this steering committee meeting, a complete review of the script was made. Many nersonal opinions of likes and dislikes in the techniques of service, proper food items and service, and preferences dominated the decision making on the script. It was clear at this time that continual changes would take place unless a deadline was established for possible changes to the script. It was agreed upon by the steering committee that no more changes would be made to the script after this revision. Ted White had speny many hours writing the script based on input from the steering committee. Copy of final script is at Appendix B. A two-day (one for rehearsal, one for shooting) time table was established for production. The projected production dates were scheduled for January 14, 1983, and January 21, 1983. Many arrangements had to be made between actors, purchases of materials, scheduling of shooting crew (FIU media), location set up, food procurement, crew assistants and labor. The effectiveness of this coordination was essential in view of the limited production time. 
January 14, 1983: The production rehearsal was, in essence, a dress rehearsal in view of the fact shooting would commence the following Friday. AII involved (minus FIU media) met at the Westview Country Club and spent the greater part of the day deciding location, angles, props, positions, narrative, lighting, acoustics.

January 21, 1983: A total of 26 people were directly involved in the shooting of the film. All labor and food products of Westriew Country Club staff were donated by Don Sheehy and the Westview Country Club. Actors from the Seminole Chapter and Sunblazer Student Chapter were volunteers. Support crew and production assistants were volunteers. Transportation costs were borne by participating volunteers. FIU media personnel donated personnel and equipment for the shooting. The only direct expense included:

$\underline{\text { Item }}$

3/4" Video Tapes

VHS Video Cassettes

Graphics

Narrator

Editing (JB)

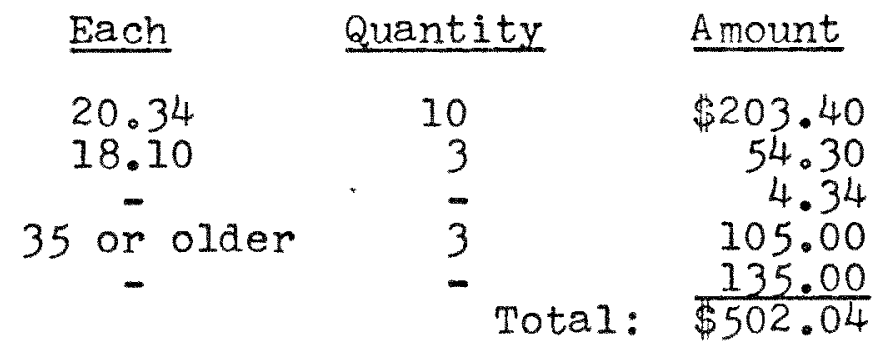

The shooting of film totaled 48 minutes of camera time which included audio. Many takes of settings were made; however, more takes would have been preferred if time allowed. The direction of the shooting was completely under the control of Ted White. Its success would not have been possible without his vast prior experience and expertise. Participating members 
arrived on the scene at 11:00 A.M. and the concluding scenes were shot at 9:30 P.M. Control, patience, and good direction led to the success of the shooting session.

\section{January 22, 1983-March 2, 1983: During this period} extensive rough editing, narration dubbing, musical score adition, and final editing was completed in the FIU Media Center.

The narrator was a professional broadcaster. The musical score was written and performed within the FIU School of Music (This alleviated any possibilities of copyright infringements). The FIU Media Center was lacking in the proper equipment to fade and add the audio, thus the quality of audio was not up to expectations. If a commercial firm with extensive equipment would have been hired (at a considerable expense) the quality could have been improved. Additionally, since State production equipment was used, individual credits such as actors' names, production names, etc., could not be illustrated as credits on the film. The film was copyrighted by The Sunblazer Student Chapter (FIU) and the School of Hospitality Management, Florida International University.

Also during this period a thought provoking written examination to accompany the training film was written and published. Copy of accompanying examination is at Appendix $C$.

March 2, 1983: The premiere showing of the film was accomplished before an audience of Seminole Chapter Members at 
their monthly meeting. The film was well received. At the meeting a survey was taken among the managers to determine how many of them would buy the film for use in their clubs and how much should be charged for the film. Many managers stated they would buy the film (influenced group) and the agreed selling price was established at $\$ 100$. (NEM Training films average over $\$ 300$ each). This selling price has been accepted by The Seminole Chapter and The Sunblazer Student Chapter (FIU).

March 13, 1983-March 18, 1983: The film was continuously aired adjacent to the student booth at the National Conference in Caesar's Palace, Las Vegas. The reception from CMAA managers was very good and unsolicited requests for copies were turned into the student booth during the conference. The film was critiqued by the best in the business and only favorable comments were voluntarily received by Sunblazer Student Chapter Members attending the conference.

The fourth objective. The fourth objective is to encourage the National Directors and related committees of the Club Managers Association of America to endorse the concept of student chapters annually producing a videotaped training film library dedicated solely to the management of clubs. Inclosed as Appendix D of this study is correspondence to the National Office outlining the proposal, requesting adoption, and outlining responsibilities of all parties concerned to implement this project. The action will go first to the Information, 
Research and Publications Committee and then will be presented for vote by the Board of Directors.

Ms. Julie Bebardeleben, staff representative for the IRP Committee at National Headquarters, endorses the concept of producing videotaped training films to facilitate easy training techniques in clubs and advancing the educational goals of the Association. She has professional background in broadcasting and was enthusiastic about the concept. The response received from the National office will clearly represent the success of this fourth objective. 


\section{SUMMARY AND CONCLUSIONS}

\section{Summary}

This project has been successful mainly due to the contributions of all parties involved:

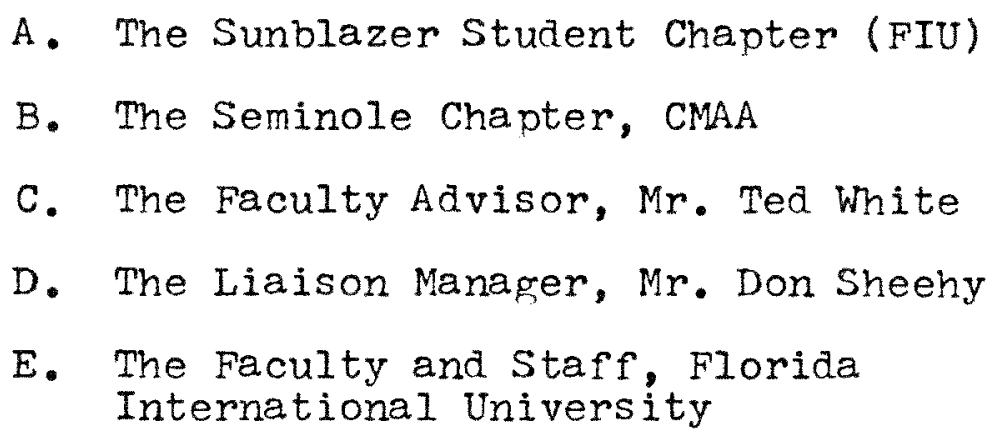

It has taken many months of planning, organization, meetings, detail writing, research, cooperation, coordination, and voluntary contributions of time and talent of those participating. It is not an easy project to undertake for people outside the field of film production. It requires a special expertise in film producing. It is even more complicated working with the limited budget and at the same time trying to achieve a quality presentation. It requires a driving force to cause all of these aspects of the project to materialize, and thankfully this writer was able to provide that ingredient.

Conclusion

Hopefully this project will not be concluded. Instead, this project will be the start of continuing benefits in education and financial assistance to all student chapters of CMAA and to the overall goals of the Association. 
A PPENDICES 
APPENDIX A 


\section{FLORIDA INTERNATIONAL UNIVERSITY}

TAMIAMI CAMPUS. MIAMI, FLORIDA 33199. (305) 554.2591

HOSPITALITY MANAGEMENT

Student Develcpment Committee

Club Managers Association of America

7615 Winterberry Place

Bethesda, Maryland 20817

Dear Committee Members:

This cover letter will serve as a supplement to your approved entry form for the 1982-1983 Student Chapter Achievement Award Competition. Paragraphs will coincide with numbers and letters printed on your scoring criteria.

Paragraph IA: Admittedly our chapter has been negligent in the proper recording of meeting minutes. The dates listed on the entry form not accompanied by minutes were reconstructed from personal calendars, training film minutes, or from correspondence to the membership announcing future meetings. This material follows page 5 of entry form. Most business meetings were held at the Hospitality School. At least one member from the student chapter attended each senior chapter meeting and reporter that activity back to the membership. Two senior members were hosted by the students to address a club management class at the University.

Parapraph 1C: One field trip this year was simply outstand ing ard beriefited those attending tremendously. Roger Omlie, Pine Tree Country Club, DelRay Beach, Florida, with three other CMiA Club managers from Indian Creek, DelRay Dunes and Quail Ridge Country Clubs, treated fourteen student members to as orientation visit to each of the clubs which are located within a three-mile proximity of each other. At one club a specific topic such as "Relations with the Board of Governors" was discussed, another subject at the second club, etc., culminatine with a luncheon with all students and managers.

Samuel Smith, George Martin, Roger Weger, Terry Clark, Mike Nelson and Gary Tohiczyk have all worked in clubs.

1 Paragraph 4B: As a result of membership in the student chapter and at endance at the National Convention, Patricia Lyone vill be employed by the U.S. Army in Germany as a club assistant manapen and Marsha Hemnstrad will be employed as the 


\section{FLORIDA INTERNATIONAL UNIVERSITY}

TAMIAMI CAMFUS. MIAMI. FLORIDA $33199 \cdot(305) 554.2591$

HOSPITHIITY NIANAGEMENT

assistaint food and beverage manager of the Memphis Country Club.

Ferporaph 51: The most important aspect of our student cherier activities this year has been the development and production of a video-tared training film entitled, "Your club: It Sorves $z$ cu Right." $\Lambda$ rroject paper covering this subject is i.i.iuied as Irclosure 3. The completed video cassette (VHS) ines reen provided the committee under separate cover.

Tinis troject took the expertise, experience, knowledge, tr. sur, time, drive and perseverance of all involved to complete. Euria reotirg in the develonnent stage was an education in itself. Irve vempit in the develoment and production required working whit surior mitagers, the liaisor manager, the faculty advisor, an employess of clubs. The students involved with this project Fin rore insight irio the operations of clubs than could have r.en rossible in a clas room.

Zcur attention is irvited to page 26 of the project report that defls suecifically with the video-training film produced cn: crat valy with the South Florida Seminole Chapter.

Respectfully Submitted,

TERRY CIARK
President, Sunhlazer Chapter

TLD WIITE

Faculty Advisor 


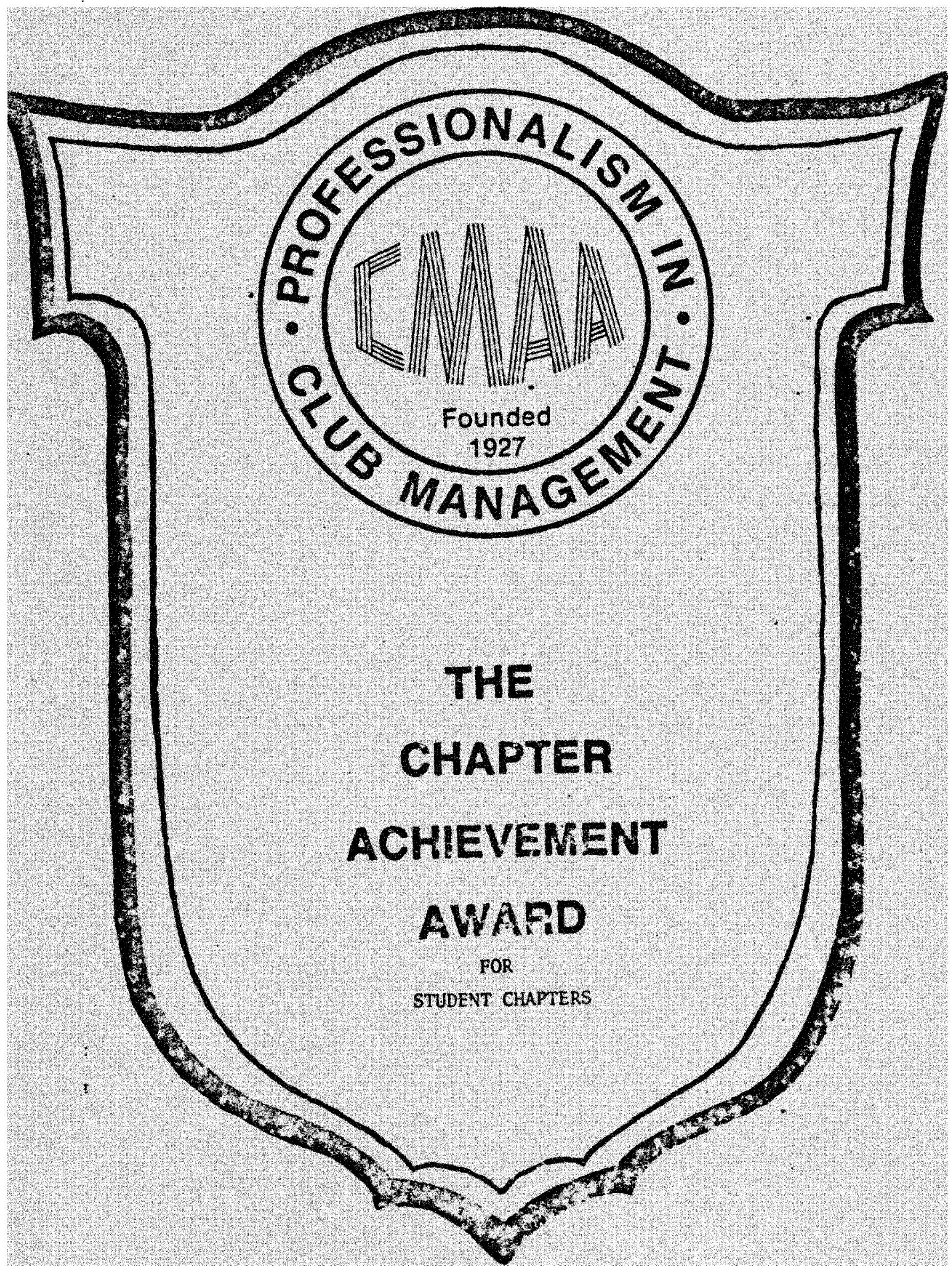




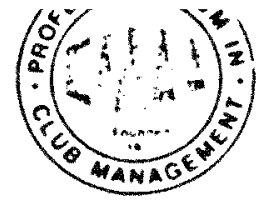

STUDENT CHAPTER ACHTEVENENT PROCRM

A. SUBJECT

The chapter achievement program is one of recognition by the Club Managers Association of America for outstanding work and successful accomplishments by the student chapters within the association.

Chapters summarize and document their involvement in activjtics and present the results to the association for evaluation and finally for appropriate recognition at the Annual Conference.

The Chapter Achievement Program is separate from the Chapter President's annual report. The association bylaws require all Chapter presidents to submit an annual. The chapter achievement program is optional and has no requirement for participation.

\section{B. PREPARING THE ENTRY}

Participating chapters are required to complete an entry form which has been approved by the Student Development Committee. Additionally, the chapter may use any supporting data and information they wish to accompany the form.

The quality, appearance and substance of supporting material will also be evaluated and will become part of the judging criteria.

Entries must be submitted to the National office no later than July 31 , unless otherwise noted. The entries will contain material pertaining to the chapters' activities for the entire school year (Sept.-June). The entries will remain in the possession of the National office. Chapters who wish to have their entries returned must provide for appropriate arrangements.

C. JUDGING

Judging is the responsibility of the desiginited committee. Primary areas for judging are:

1. Eduational Programs

2. Membersing growth

3. CMA involvement and published articles

4. Fmployment in clubs

5. Special projects

\section{AWARDS}

The committee will present a traveling trophy awad to the chaptor seleitod as the vinner with a miniature trophy to be kept by the winning chapter. other appropiate recogniton will be extended to other entries 


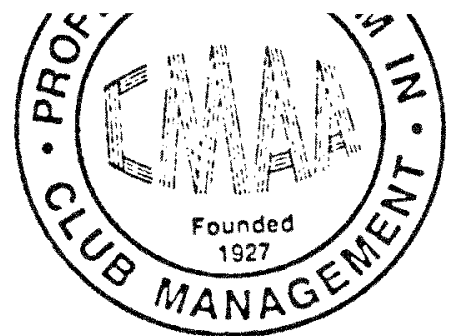

CRITERIA FOR SCORING POINTS FOR

STUDENT CHAPTER ACHIEVEMLNT AWARD COMPETITION

\section{SUBJECT}

SCALE OF:

1. EDUCATIONAL PROGRAMS
A. Include copies of all chapter minutes
(How do these programs relate to club management?)
B. Chapter meetings
Social/business/educational/ fund raising
C. Field trips

2. MEMBERSHIP
A. Nembership growth by percentage
B. Number of new members
C. Attendance of meetings by percentage

3. CMAA INYOLVEMENT and PUBLISHED ARTICLES
A. Number of members attending Conference
B. Number of members attending Regional Meetings
C. Number of members attending senior CMAA Chapter meetings
D. The chapter's contribution to student chapter development
E. Authored articles appearing in Club Management magazine and OUTLOOK. (Include articles)

4. EMPLOTMENT IN CLUBS

A. Number of members that have/are employed at clubs (state names)

B. Number of members that graduated and entered the cluh management profession (state names)

5. SPECIAL PROJECTS

A. Could include: research in special projects as it relates to club management; working with clubs solving problems

POINTS TO BE EXERCISED BY COMNITTEE JUDCEMLNT

I A. These points will be based upon the chapters' achievement and growth as it relates to the progress of the chapter and club management and quality of the cntry itself. 


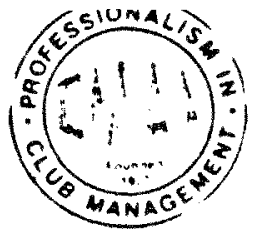

STUDENT CHAPTER ACHIEVEMENT NHARD COMPETITION

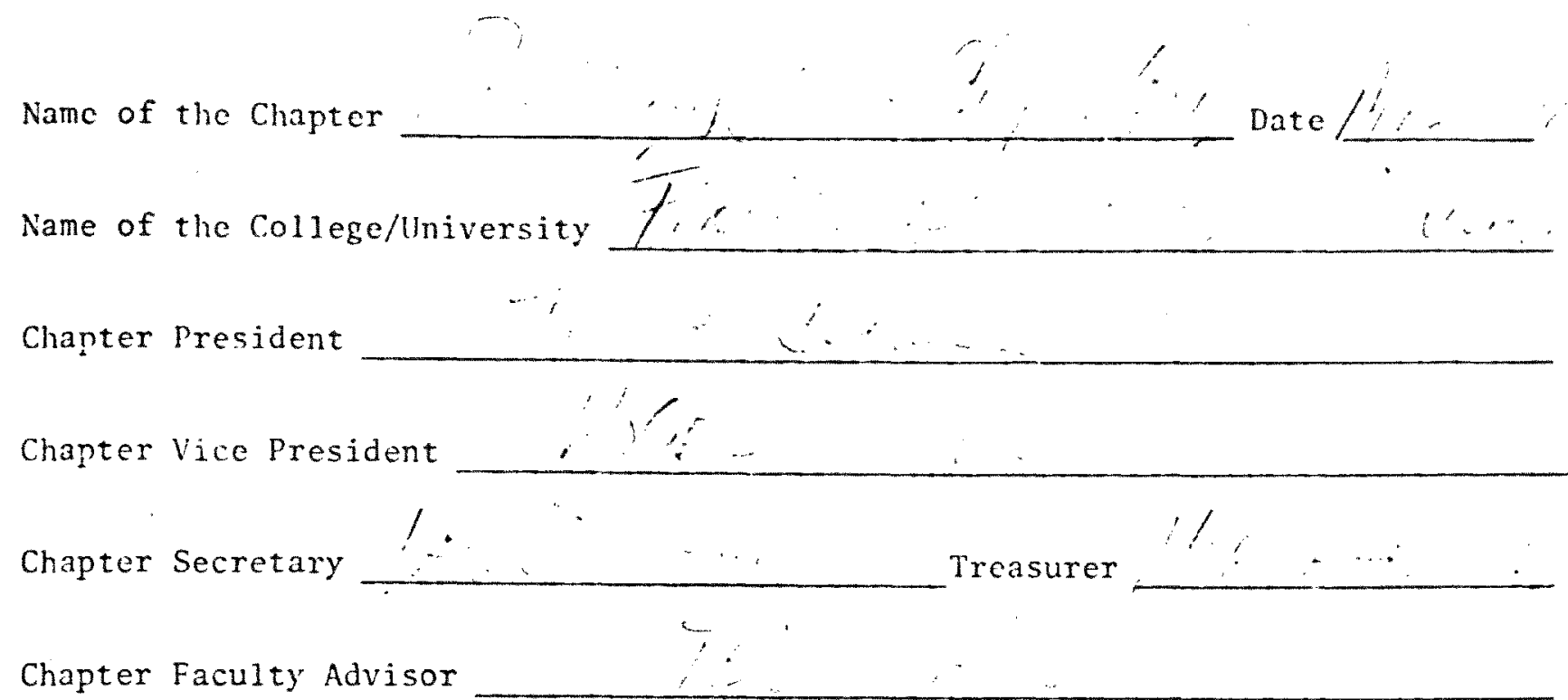

Chapter Liaison Manager

Sponscring CMA Senior Chapterfot

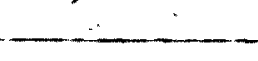


1. EDUCATION (Inelude-minates of the meeting)

A. Type of Meeting (social/business/ educational/fund raising)

EexprontL

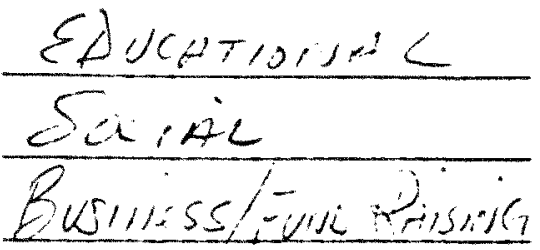

$\frac{\text { Elevation- }}{\text { Pucris/fwe }}$

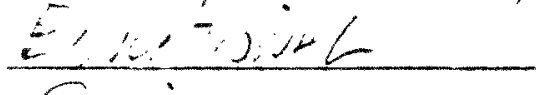

Sciatic

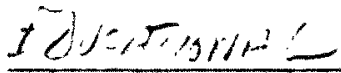

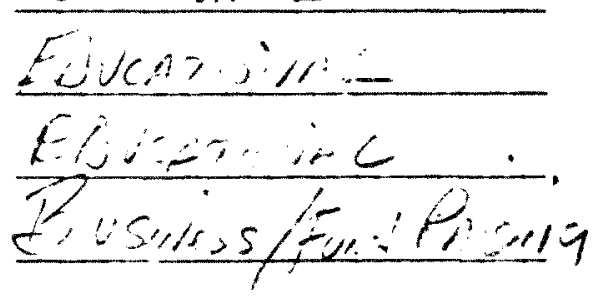

TOTAL

C. Field trips

(where and senior chapter)

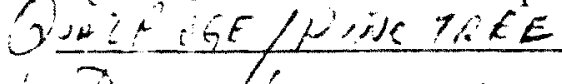

1).

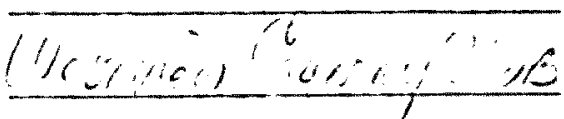

TOTAL
B. Date

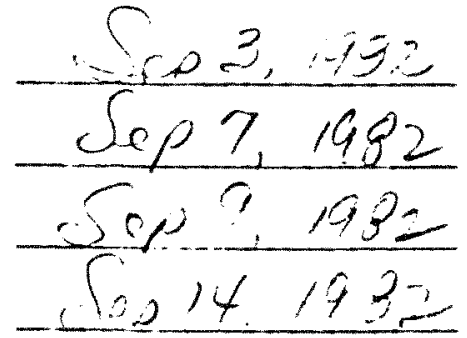

OCT 13,1902

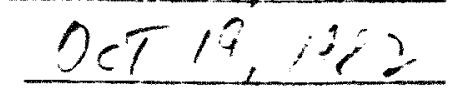

\begin{tabular}{l} 
NoDI? 32 \\
DEC 14.082 \\
\hline$T_{11} 13.03$
\end{tabular}

$\frac{71,14,983}{-1,121,103}$

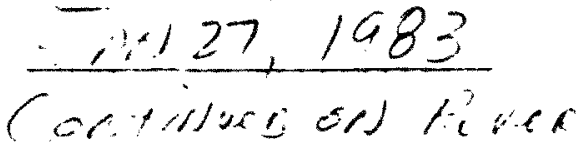

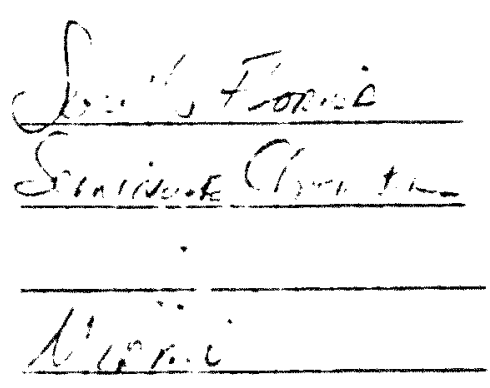

2
Members Attending (number)
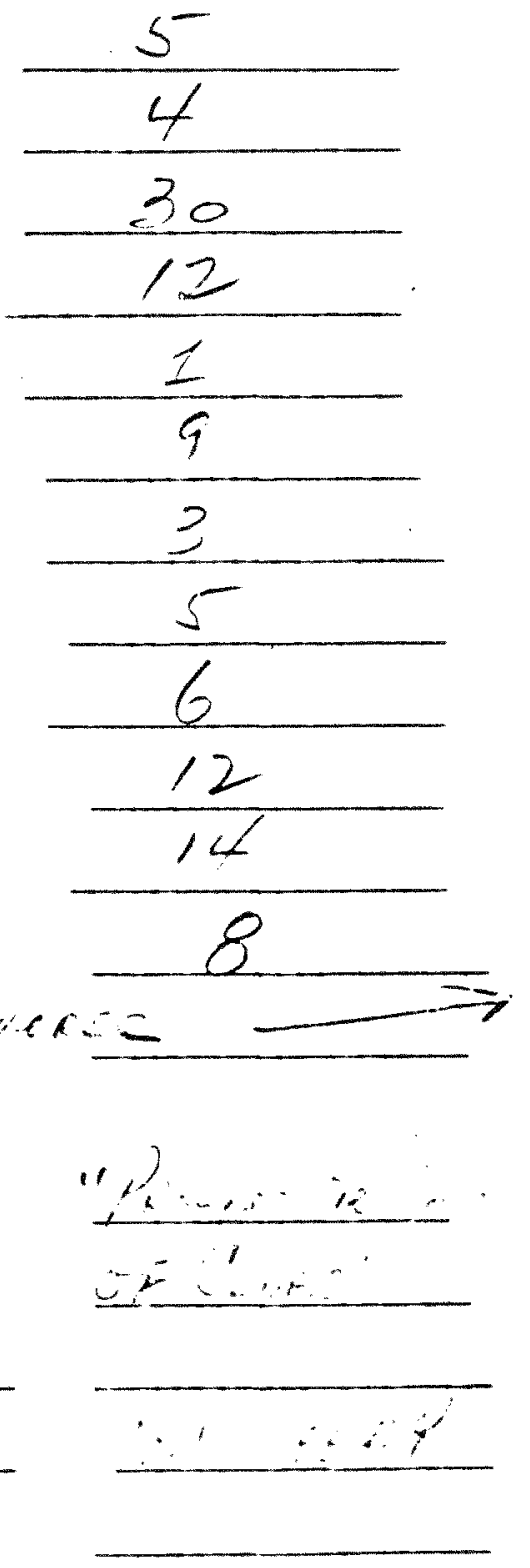

2. MEMBERSHI!

A. The number of members in the chapter in September 55

B. The number of members in the chapter in June

C. Membership growth (in rease/decrcasc) by percentage

D. Number of new members recruited into the chapter this year ${ }^{\circ}$

E. Average number of members who have at tended chapter meetings throughout the year. (State in percentage)

4 
3. CMAA INTOLVEMENT and/PUBLISIED ARTICLES
A. Number of chapter members at Conference time 31
B. Number of members attending Conference
C. Number of menbers attending Regional Meetings
D. Number of members attending senior CMAM chapter meetings
E. Include items that relate to the chapter's contribution to student chapter development.
F. Include article appearing in Club Management magazine and OUTLOOK. How many are there?

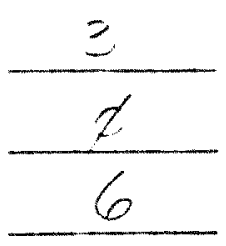

4. EMPLOYMENT IN CLUBS

A. Number of members that have/are employed at clubs

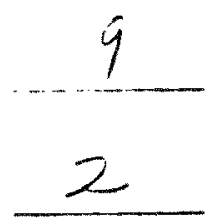

B. Number of menbers that graduated and have entered the club management profession.

5. SPECIAL PROJECTS

A. Include in the entry a copy of the project with all pertinent information need so that the committee can judge appropriately

POINTS TO BE EXERCISED BY COMMITTEE JUDGEMENT

FOR OFFICL USE ONLY: 
Members Present

1. Terry Clark

2. Rocer leger

3. Phil smith

4. Patricia Iyons

5. Steven Cor"is

6. Charlie Denth

7. 111 Cheever

8. Marsha iemnsted

9. Neghan Beete1

10. Ray Valentino

11. Pete Martin

The meeting was called to order by President Terry Clark at $11: 30 \mathrm{am}$.

\section{Treasurer Report:}

Trasurer foger fieger stated that as of 6 july 1982 there was $\$ 159.40$ in the Club's treasury.

The letter has been written to stouffer's for the reinbursement of $\$ 75.00$ spent on decorations for our 16 march reoreanization function.

The student foverment Ascociation has established an account for use by che in the amount of $\$ 25.00$ for the fiscal year.

Flection of offiners:

A motion hy Phil smith that the club's nfficors acoume their duties at the beginning of each gatl semester and their term run throush the end of spring semester. parricip Lyons secont the motion. "he motion carries.

\& motion by Pete piartin that officer elictions he condicted in tpril of each year wes second by pasricia lyons and unanimonsy" carried.

Prosident Glark eoked for a response of individhels itoprestec in filling the varant wostions of semothe and for twosumm

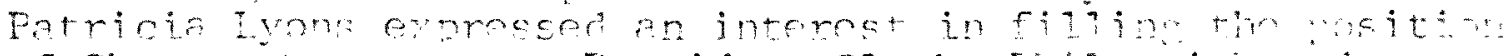

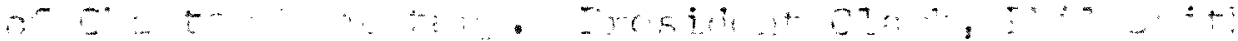

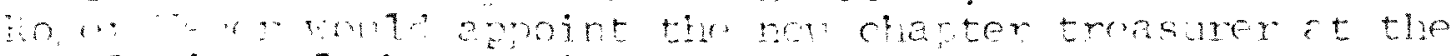
conclustion of the meeting.

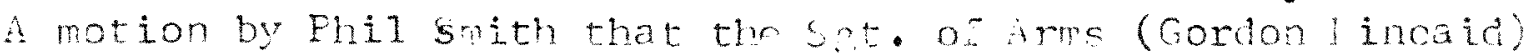
w whitting to remain in his position, waher than move lo to the vacatei position of somrotary as stated in the Chanters constitution was intenduced. The motion was secomi by ill?

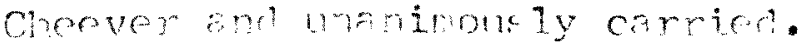




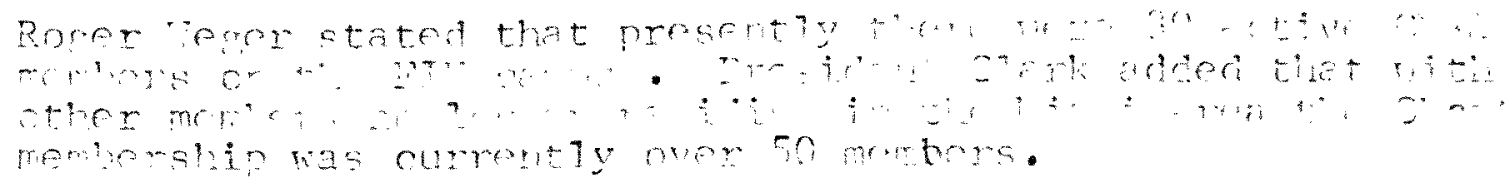

Presidont clark stated thet the chapter moded to ponerate f funds in orier to send student gh mowe ton the detionel

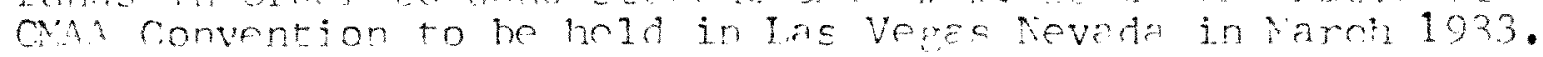

Fresident clark refered to a ciscussion thich he wa lat with Mr. Cere "arshal1 to develon a video tane on the subjert of service in a clib envioment. The tape would be made heje at EIll and marketed nationaly to diA clut kargere on a purclase or rontal amrement. This project will be undertaken this pal1 and till nopd the total supnomt of a 11 the etudent min members.

Presilent Terry Clark then solicited the members for other fund raicing ideas.

Meghan Beetel surgested the selling of lemnn-aide and ire-tor at a public bonch.

Presilent Terry Clark asked Nephan to acnept the position nf Fund Paiaine Ciajperson.

A pronosal by steve cordes to conduct a raffle was suegesto The prizes of the affle wnuld include donated dinner by the Yjami area hotels and restamants. Frfessor wite offered to assist in the aquiring the tickets reguired for the raffie.

Propresaive Clut Day:

Preaident Terry clark read the letter of Rorer Omlie concernine the Proeressive Club Day. Nembers attending will meet at 8:00 am on saturday 10 .uly in the DW Parking Lot a car pon 1 will he formed with w expected arrival at the quat Ridge country club at $9: 20$ am. The dress is casual for this function.

other Business:

President Terry Clerk supgested that the Chapter hava a narty in the early nart of the Fall semester in conjunction with $a$ membershin irive.

A CAA bonth in conjunction with the SGA orientation will be looked into to increase the cllb's mombership.

Will Cheever supgrsted that a party on board a fishinp boat which could be themed as "A liejcome Abnard Pai "y" be persued. Will has been asked to research the foasihility of such ting.

A motion was made by fete Martin that the meetine be ad purned and theond by phil smith the mofion was unanimous ty carried 
A special canmittee meeting was called to order at 10:07 am September 3, 1982, for discussion on the service videotape.

Members in attendance: Terry Clark

Marsha Hempsted

Patricia Lyons

Gordon Kincaid

Professore Ted White

Guests from Seminole Chapter: Gene Marshall

Alfred Bassato

John Gerecter

Don Sheehy

The meeting was opened with an opening statement by Gene Marshall. Gene stated that this film on service of Country Clubs and catering is a Student Acheivement Award program. The directors will be awarded $\$ 500$ to get the film underway. The proceeds of the produced film will go to the student chapter.

Professor White has taken the job of writing the script and the production of the film. He proposed we go through 6 points needed for starting the production.

1. Script - Professor White will make a broad outline. The script is directed to Country Club Service. It will consist of both services (American Club Service and French Service) We will have 4 couples at 2 tables.

Gene Marshall brought up the point on - how to make a training video tape as a project in itself.

2. Shooting - It was agreed by Don Sheehy to have the shootingidone atiwestiview.

3. Actors - The people that are professionals in the service area will be used. A mixture of students of the Sunblazer Chapter and members of the Seminole Chapter will also be used.

Terry Clark suggested on equal mix of jobs for professors, students and managers for casting due to the Student Acheivement Award approach.

4. Iocation and Props - The location is at Westview and props will be accessible at the location.

5. Finances - We will need the production professionally edited. Rehersal will take one day. Shooting will also take one day. (]0 hours) Payment for transportation and labor.

The $\$ 500$ given to us by the Seminole Chapter will be placed in the bank and we will draw separate checks as the production goes on. 
6. Releases - They will be needed to use the club and for all the actors in case of any accidents. (legal purposes)

Professor White will have the broad outline out in the mail to Gene, Don, Alfred, and John for reviewing and comments by Wednesday, September 8. Then a follow up meeting on Friday, September 17, at 10:00 am in Professor White's office. Five working days will be needed for campletion of the script after reviewing.

The video will be considered as CMAA property for circulation.

The question was brought up about copywriting the videotape. Don Sheehy will follow up on the particulars.

The cormittee decided to sell the tape to other country clubs. The price will be determined after the production.

The deadine for completion will be January 15, 1983.

Meeting adjourned at ] ]: ] ] am.

Patricia Lyons

Secretary, CMAA, Sunblazer Chapter 
The second special committee meeting on the videotape "Your Club-It Serves You Right" was called to order at 10:05 A.M. September 7, 1982 .

Members in attendance:

Terry Clark

Marsha Hempsted

Gordon Kincaid

Roger Weger

Professor Ted White

Guests from the Seminole Chapter:

John Gerecter

Gene Marshall

Don Sheehy

The meeting was opened with discussion of the script Ted White had written and mailed to committee members and advisors.

It was suggested that a title be chosen that indicates the videotape is oriented to club service tather than the current titie- "The Art of Dining", that suggests all phases of hospitality dining.

The favored two suggestions were:

1. The Right way in Club Service

2. Your Club- It Serves You Right

From these, the latter, "Your Club- It Serves You Right" was chosen.

There was total agreement on the scripts stated subtitle and the discussion moved on to the length of the tape. Gene Marshall remarked that the length of the example film on service shown last week was short enough to be interesting but long enough to get the information across correctly. That film lasted approximately 15 minutes. Professor White agreed to write the script with a 10 minute minimum and 15 minute maximum time structure in mind.

A menu for the film was decided that would be colorful and pleasing enough to photograph well and also portray the expert culinary efforts available in clubs today. (The written menu will be given at a later date).

In order to demonstrate two common types of service in the club field, the members agreed the two tables would have varying types of service. 
Table \#1-American Club Service (Plate or silver Dervice) with chocolate souffle and coffee for dessert.

Table \#2-French Service (Or Semi-French with either Chef or Waiter Captain serving tableside) with a Iessert Cart and Cordial Cart after dinner.

The following variations in the script were suggested and agreed upon.

1. Scene 1:

Valet Parking a Bentley (or other prestigious car reflecting "Westviews"elite membership.Compliments of Don Sheehy!)

2. Scene $2 \mathrm{a}$ has been added:

Camera shot of dining room full of happy guests. * Actors and Actresses to ue Sunblazer chapter members, Seminole chapter members, and various WCC members, all to be decided on next meeting.

3. Scene 8:

White wine and not Champagne will be served at table \#2.

The Host at Table \#2 will be giving all the orders.

4. Scene 11 or 12 :

Separate Checlis are to be mentioned for Table \#1.

5. Scene 12:

Appetizers are ordered for table \#1.

6. Scene 19A:

Appetizers are served at Table \#1.

7. Scenes 16-21:

In one or more of the Westview Country Club Manager DON SHEEHY will appear in the dining room to greet his members briefly.

8. Scene 23:

The phrase "Thank-you very much, please come again" was to definitely be emphasized in the script.

- Maitre'd or Waiter/Waitress appears at table to help with their wraps.

9. Scenes 24-25:

Chef in uniform will be appearing to brief the servers on the menu. 
10. Scene 11:

The llaitre'd will be the inspector of the Dining Room set-up. A complete inspection will include:

A. Seats Brushed

B. Plates positioned correctly with the total setting and in-line with the seats.

C. Clean and Flawless linen service.

\section{A Personnel Inspection Including:}
A. Nàis
B. Niake-up
C. Hair
D. Jewelry
E. Proper Dress

Flower presentations on table were suggested and to be further discussed at the next meeting.

It was agreed that the $\$ 500$ gift from the Seminole chapter would be returned by the Sunblazer Chapter upon the receipt of proiits from the sale of the first videotapes.

The next discussion centered on possible further teaching benefits of the videotape. It was suggested that 3-5 questions would be printed on the end of the film with yes, no, $A, B$, orC answers. An example would be: The entree is served from the-

A. Right

B. Left

C. Over every members head

The narrator of the film is yet to be agreed upon, but there are a few favored candidates in the running!

There was a brief discussion of possible future training films if this film is a success.

Everyone around the table offered their congratulations and thanks to Ted White and his well detailed script and organizational abilities.

The Meeting was adjourned at 11:15 A.M.

* * The original meeting scheduled on October 8, 1982 has now been scheduld for Wednesday, October 13, 1982 and will still be held at Don Sheehy's Westview Country Club.

Marsha A. Hempsted

Treasurer, CMAA, Sunblazer Chapter 
Nembers Present

1. Patricia Lyons

2. Will Chepver

3. Pete Martin

4. Brain Lawrence

5. Paul D'Anirea

6. Steve Cordes

7. Farsha Hempsted

8. Ted Shite

9. Bob Shoomer

10. Cordon Kincaid

11. Roger Veger

12. Terry Clark

The meeting was cilled to order by President Terry Clark at $12: 20 \mathrm{~nm}$.

The minutes of the last meeting on Tuly 6 , and minutes of the special committee meetine were read by Secretary Patricia Lyons.

other Corespondence:

Christmas Party at lestview by Don Sheehy on Dec. 14.

Professor hite expressed that it would be a gond idea to attend. It is a couple affair and if you are interested let Professor White Know.

Dinner Party at Delray Beach Club on Nov. 11.

Treasurer Renort:

New Balance is $\$ 238.09$.

Treasurer Narsha Hempsted chancied banks due to heavy service Charfes.

Fund Raisers:

Mephan Beetle was not at the meeting and we will wait for a report the foloowing meeting.

Nembers'in Drive:

Vielcome Aboard Party is under construction by $1: 11$ Cheever. lie have a choice of places we cen use.

Terry slark expressed that finding a place was not the arohlem it's the funds.

Theose invited to the prety are chapter members, new members, and raffle ticket holders. 
Vide Project:

Special committee me ting will be held on sept. 17 with members of the Seminole Chapter.

Marsha Hempsted has shown an interest in documenting the film project.

The purpose of this wide is for the Idea Generation Award in March and also to raise money.

If we receive endorsement from Horace of CMA we can receive $\$ 100$.

Money will go to CiA Student Chapter.

Goals of Last Year:

We failed our goals by not petting jobs for Chit members. Te must be around Seminole Chapter Meetings etc. to eft exp esd.

Our next meeting will be on october 13: Tuesday at 12:15 roo m 144. Marsha will make sure that it is 11 publicized.

Meeting was adjourned at $1: 00 \mathrm{pm}$. 


\author{
FIU SUNBIAZER CHAPTER \\ SEMINOLE CHAPTER, FL. \\ SPECIAL VIDEO TAPE CONMITTEE \\ october 13, 1982
}

The third special committee meeting on the video tape "Your ClubIt Serves You Right" was called to order at 10:08 a.m. October 13, 1982 .

Members present from Sunblazer Chapter: Marsha Hempsted and Frofessor Ted White.

Nembers present fron the Seminole Chapter: John Gerecter, Gene Marshall and Don Sheehy.

Meeting was brought to order by Gene Marshall with discussion on the Student Achievement Award. He expressed regret the National CMA.A wouldn't be opening this category for competition until the 1984 convention. He then questioned the possibility of using this video tape for the student category in 1984 with a positive answer.

Next discussion was on what category to submit the viceo tape in for the Seminole Chapter. Upon advice from Charles Smith, the following three were decided on:

$$
\begin{aligned}
& \text { a. The Educational Award } \\
& \text { b. The Idea Fair Award } \\
& \text { c. The Chapter Award }
\end{aligned}
$$

Gene Marshall then suggested an educational program be marketed along with the film such as the National Educational Media presents. This consists of a sheet with multiple choice questions on the films. The Nem materials were then turned over to Ted White to prepare an example questionnaire to be presented at the next meeting.

The next discussion centered on the new script Ted white prepared and presented. Ted has provided camera shots, the audio, camera focus, and time spans in the new script. The script and prop list are to be reviewed and commented on by the special committee members at the next meeting.

The subject of the narration once again came up with Ted White taking suggestions and the final responsibility for finding the indiviaual of distinction with a resonant voice.

Movie background will be provided by Ted White. Music must be changed in order to be unrecognizable, otherwise it is distracting.

Gene Marshall volunteered to bring the topic of the video tape up at the Seminole Chapter meeting Tuesday, October 19, 1982. Volunteers from both the Seminole and Sunblaxer Chapters are definitely required to produce the film. 
FIU SUNBIAZER CHAPTER

Special Video Tape Committee". Minutes

october 13, 1982

Don Sheehy volunteered his WCC staff for the employees in the film, with a male/female team doing the serving.

The eight guest actors in the film will be: John Gerecter and wife, Gene Marshall and Don Sheehy's wife, Walker Brown and Sunblazer Chapter student, and Terry Clark and wife.

John suggested alternates be chosen in case all actors were not available.

Dress of the actors and actresses was decided to be formal. Jackets with ties for men, dresses for women.

The marketing aspects of the film was brought up by Gene. He suggested a mailing piece as was used by the Minnesota Restaurant and Food Association for their training films. The example and proposal was turned over to Ted White for input at the next meeting.

Don and Ted have the menu all planned out. The subject of cost, due to repetitive shooting and food preparation, came up. Financial arrangements will be discussed later.

Discussion on copyright aspects of the film were tabled until Don's legal lawyer has a response from the contacted copyright lawyer.

Ted estimated the films maximum expense to be lower than initially expected. A mere $\$ 15$ a film? Three years ago NEM marketed their films for $\$ 5$. The price for our video tape is still pending.

The final subject was raised by Gene as to the feasibility of sunblazer Chapter students attending the NationalCMAA Convention in las Vas. Possibly arranged by advance film sales in the Seminole Chapter.

Ted White provided some possible answers:

Lodging - Provided in University Lormitories, free of charge. Registration - Horace Duncan usually wases registration

fees for students.

Meals - Must pay the required members price.

Transportation - $\$ 278$ round trip.

The next special committee meeting is scheduled for Friday, October 22, 1982, at 2:00 p.m. at the Westview Country Club.

Meeting adjourned at 11:10 a.m.

Respectfully submitted, Marsha A. Hempsted

Treasurer, CMAA Sunblazer Chapter 
APPENDIX B 

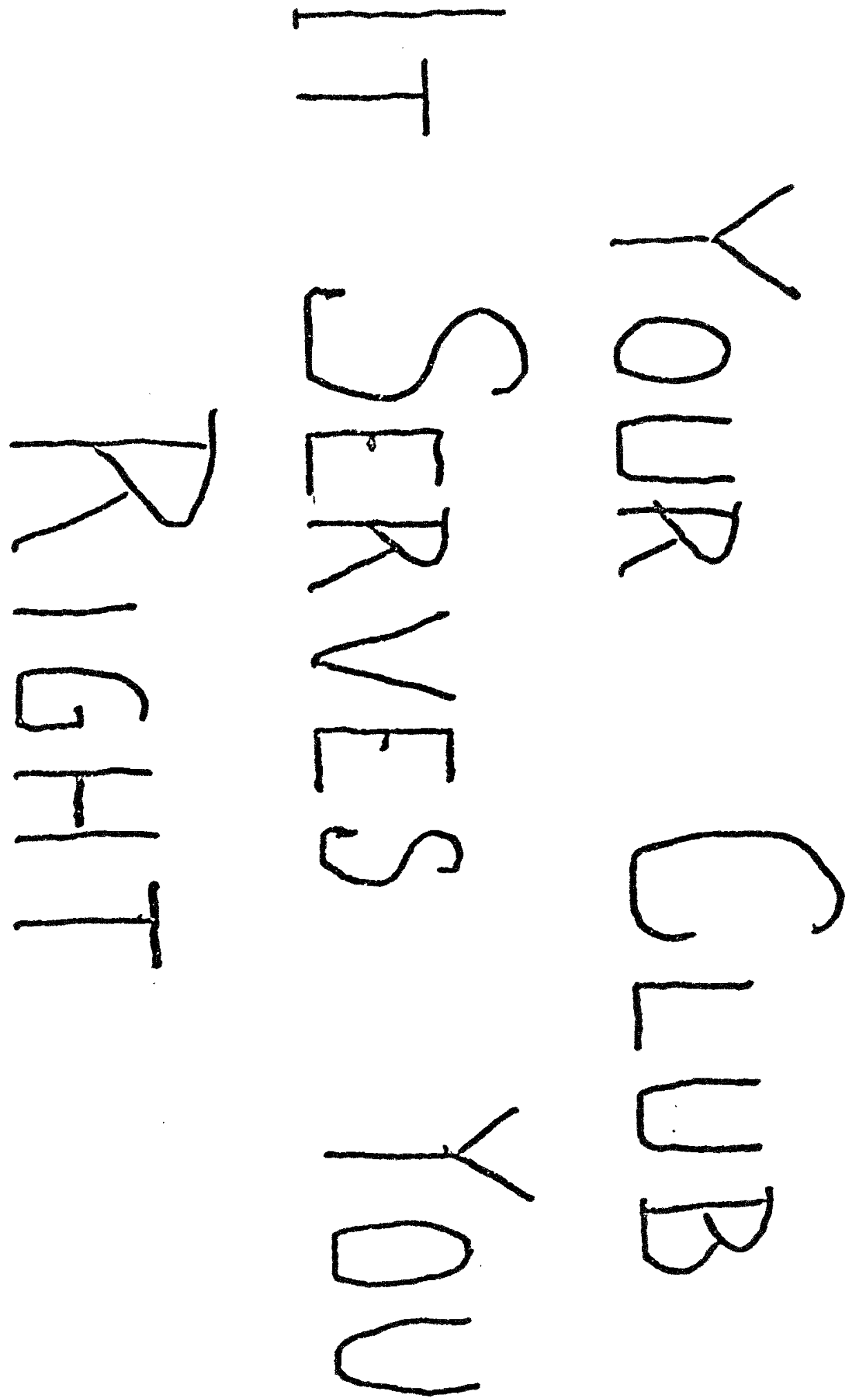
DESIGN SHEET - SCRIPT/STORYBOARD

PAGE\# 1 OF

PRODUCPION SCRIPT

SCENE

TITLE YCISYR

NUMBER

DATE

October 1982

"Your Club It Serves you Right!"

Intro music fade in

music to conversation level. 
CMAA T.V. PROGRAM

DESIGN SHEET - SCRIPT/STORYBOARD

PAGE\# $O F$

PRODUCTION SCRIPT

TITLE YCISYR
SCENE 1

NUMBER
DATE

\section{CAMERA}

Camera in back

of pickup truck

aimed straight on

to club entrance

Park truck about 12 '

from entrance door.

Tilt up to transom. M.S.

\section{VIDEO}

Center the name of club "Westview Country Club."

\section{AUDIO}

"We, you and I, have been invited to spend an evening observing the operation of the Westview Country Club dining room. Here the food and service is 'considered the very' best.

"Gene Marshall is Chairman of the film project and the other C.M.A.A. Seminole Chapter Committee members are: Alfred Bassato, John Gerecter and Don Sheehy."

MUSIC

Back ground music continues. 
CMAA T.V. PRUGRAM

DESIGN SHEET - SCRIPT/STORYBOARD

PAGE\# OF

PRODUCTION SCRIPT

TITLE YCISYR
SCENE 2

NUMBER
DATE

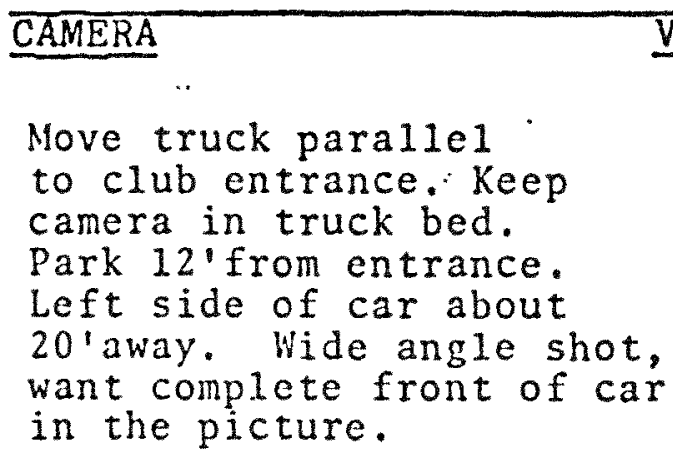

Car is parked about $20^{\prime}$ from club entrance. On signal car slowly approaches, stopping at entrance. Car's approach is to be as far as possible from the steps.

\section{AUDI0}

NARRATOR

Narration continues, "The Club valets are on hand to park cars from member guests.

\section{MUSIC}

Background music continues under the narration. 


\section{DESIGN SHEET - SCRIPT/STORYBOARD}

PAGE\# OF

\section{PRODUCTION SCRIPT}

TITLE YCISYR

\section{SCENE 3}

NUMBER
DATE

CAMERA
Camera position
at rear of car.
Tilt up, shoot
obliquely at attendent
coming down step. Pan
to left lowering camera
for straight on shop.
Use MS, cut at knees.
Pan right and tilt up.
Follow to landing.

VIDEO

Attendant starts down steps and approaches car. Ladies in front and back to right of driver and gentleman in the rear seat.

Attendent opens front door first $\varepsilon$ assists first lady out. She noves to the front of the steps. Attendent closes front door and opens rear door, assisting lady out.

Attendent leaves camera range around rear of car. Gentlemen enter around front.

Gentlemen join cadies and start up stairs in group.

AUDI0

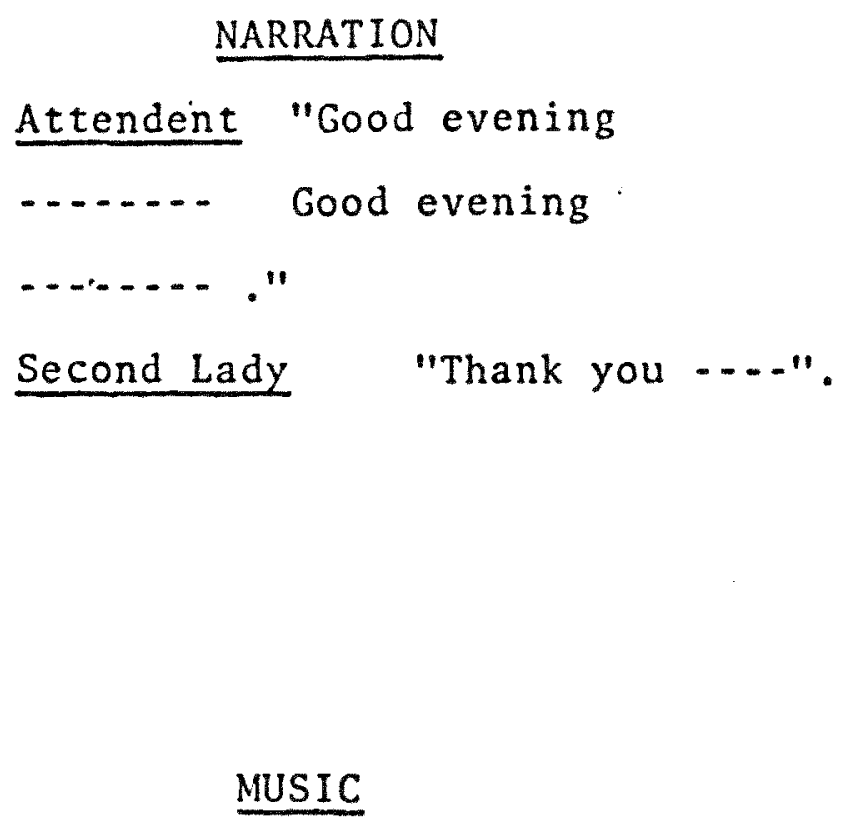

Second Lady "Thank you ....". MUSIC

Background music continues under conversation. 
DESIGN SHEET - SCRIPT/STORYBOARD

SCENE 4

TITLE YCISYR
NUMBER
PAGE\# $O F$

DATE

\section{CAMERA}

\section{Camera positioned}

in door of dining room. Slowly pans from left to right. LS focus at least $12^{\prime}$ in front.

\section{VIDEO}

Scene ta show persons dining in the dining room.

\section{AUDIO}

\author{
NARRATOR \\ "It is obvious that the members \\ fully utilize the amenities \\ offered. Note the generous spacing \\ between tables to provide a degree \\ of privacy.
}

\section{MUSIC}

Background music continues. 


\section{DESIGN SHEET - SCRIPT/STORYBOARD}

PRODUCTION SCRIPT

TITLE YCISYR

\section{SCENE 5}

NUMBER

(1)

PAGE\# $O F$

CAMERA
Position camera
on dolly inside
entrance to dining
room to right of
door. MS-oblique
pick up guests as they
appear in doorway.
Side entrance of
Maitre d. Dolly back to
include the entire
party.

VIDEO
Guests come through
the door in pairs
slowly. As they get
completely inside the
room, with the ladies
on their left and
the maitre d appro-
aches from the left.
Maitre'd stops as
guests form semi-
circle, backs to door.

AUDIO

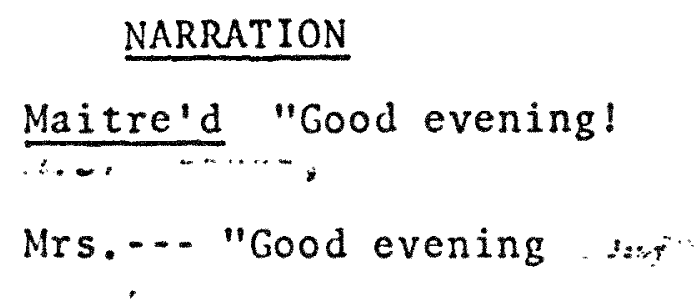

NARRATION

Maitre'd "Good evening!

Mrs... "Good evening . s:m"

,

DATE

\section{MUSIC}

Conversation under background of music, under narration to simulate crowded dining room. This is done with

minimum of eight persons (male and female) reading different news items, using at least four different voices

inflections. Background music is playing. Actors thru for same decibel level as music.

$$
\text { NAREATOR }
$$

NOTE THAT A CAPTA IN IS INSPECTING Tinis tablel as he Does ALL TABLES) TO ASSUEE HWSEL THAT IT S SET COREECTKY ANM 

OF

\section{PRODUCTION SCRIPT}

TITLE YCISYR
SCENE 6

NUMBER
DATE

CAMERA
Camera on dolly setup
at apex of triangle formed
with two tables. Tilt
down MS on table 1
Stay with table top at
bottom of picture.
zoom in for captain to
pour an oz. of wine.
for A's and C's testing.

Party of four are seated at table 1. A is the host, $D, B$ are the ladies, $C$ man. Captain is standing between $A \xi B$. The host had ordered wine as an appetizer and the captain is showing the label to $A$. The captain then removes the cork and places it in front of $A^{\prime} s$ plate. He then pours an oz. into A's blass and steps back. A tasted the wine and nods his approval. The captain then pours wine clockwise for $B$ and $D$, Then $C E_{1} A$.

Captain then places wine in bucket and exits to the left.

\section{AUDIO}

\section{NARRATOR}

"We are going to view two different types of dining that our blub offers. At this table the host and hostess have invited guests to celebrate his promotion to chairman of the Board. In consultation with the manager last week, he has planned the entire dinner to be served in tradional Fronch style with only minor variations. The 2nd table will order from the menu and be served American Club Style. In this type of service the entree is placed and garnished in the kitchen, then placed before the guest: The vegetables and potatoes are then served individually by the servor.

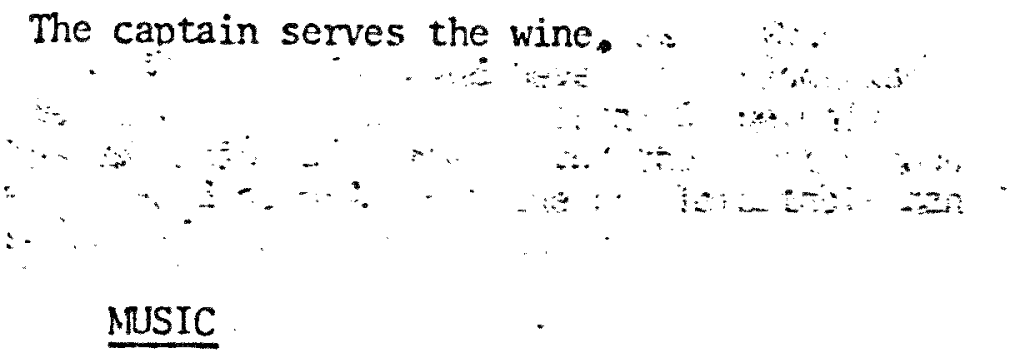

Background music continues without background conversition. 
DESIGN SHEET - SCRIPT/STORYBOARD

PRODUCTION SCRIPT

TITLE YCISYR
SCENE 7

NUMBER
PAGE\# OF

DATE

\section{CAMERA}

Camera covers

table \#2, as

Maitre di \&

captain seat guests. camera straight on

MS.

\section{VIDEO}

Maitre d' leads guests into scene followed by captain. They meat guests, Maitre d' exits to the left.

Captain stands between $A$ and $B$ to take beverage orders on a note pad.
NARRATION

Maitre d' "Enjoy your evening.

Male Guest- "Thank you"

Captain "May I serve you any cocktails?

Male Guest "YES iTitank You.

NARRATOR

The captain is taking the orders by standing between two guests. He uses the order-clock procedure. He will usually be given the ladies order first, but will leave space to put each order into it's proper place. Carrain heaveb.

THE BUSBOY SERTES WATER (NOTE THAT IHE HOUDS GLASSES BY THEIR Stanis. NEXT lTe SERVES INDIVIDUAL BREAD ANB Butree TO EACH MEMBEe wHO DESIRES it. THis is $A$ WICE 
DESIGN SHEET - SCRIPT/STORYBOARD

PAGE\# OF

PRODUCTION SCRIPT

TITLE YCISYR
SCENE

* 8

NUMBER
DATE

\section{CAMERA}

Camera on

table \#2. MS

cut in as server is serving last drink. Hold while host raises glass to propose toast. Pan left to table \#1.

\section{VIDEO}

The guests are seated at table Drinks are in front of $B, C$, and $D$.

Scene starts with servor \#2 placing drink for A along side of service plate.

A raises glass to propose toast as other guests comply scene changes to table \#1.

Servor \#1 is serving the soup course to $B$, then $C, D$, and $A$.

Captain follows replenshing wine glasses.

Guests are conversing with each other. Heads turning, lips moving, very slow action. One conversation at a time starting with $B$.

\section{AUDIO}

NARRATOR

"In our club the service plate remains on the cover until the entree is served. The service is iprompt, very gracious, but unobtrusive (never showy) and our personnel like their jobs and show it by their attitude and job performance.

They wait for the members to speak first, never starting a conversation (not connected with service). aND always with a smile."

Traditionally we serve from the left and remove from the right, with the exception of beverages".

MUSIC

Background music continued. 

OF

PRODUCTION SCRIPT

TITLE YCISYR
SCENE 9

NUMBER
DATE

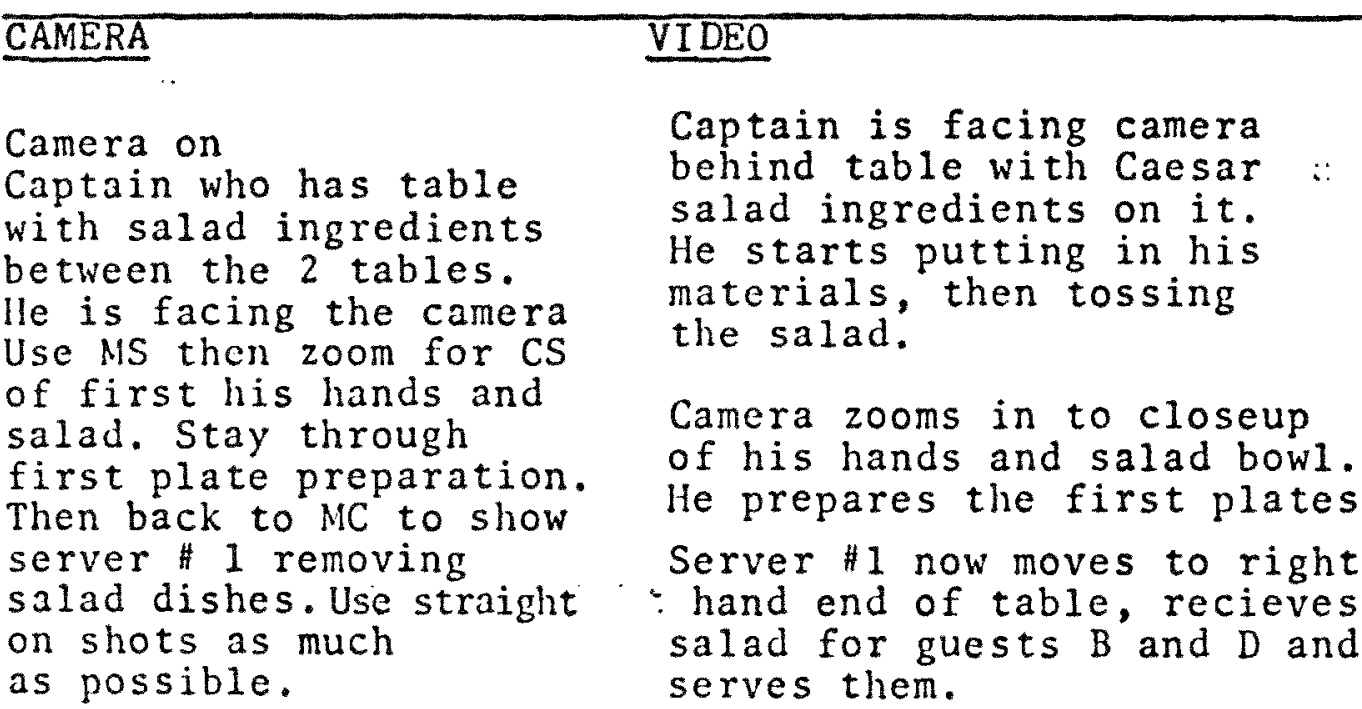

as possible.

\section{AUDI0}

NARRATOR

"We are now going to : observe the entire "French Style" dinner being served. Care is taken to see that the salad ingredients are coated with the dressing but are not broken into smaller pieces.

The plating is done so that the complete salad is in the center of the plate.

The salad dishes are removed from the right and placed on a tray under this system the table is cleared smoothly and quietly.

The servor follows two basic principles (1) he does not remove any plates until all the guest have finished, and (2) he removes (and if necessary replaces) all used flat ware.

MUSIC

Background music continued. 

$O F$

\section{PRODUCTION SCRIPT}

TITLE YCISYR

\section{SCENE $\quad 10$}

NUMBER

DATE

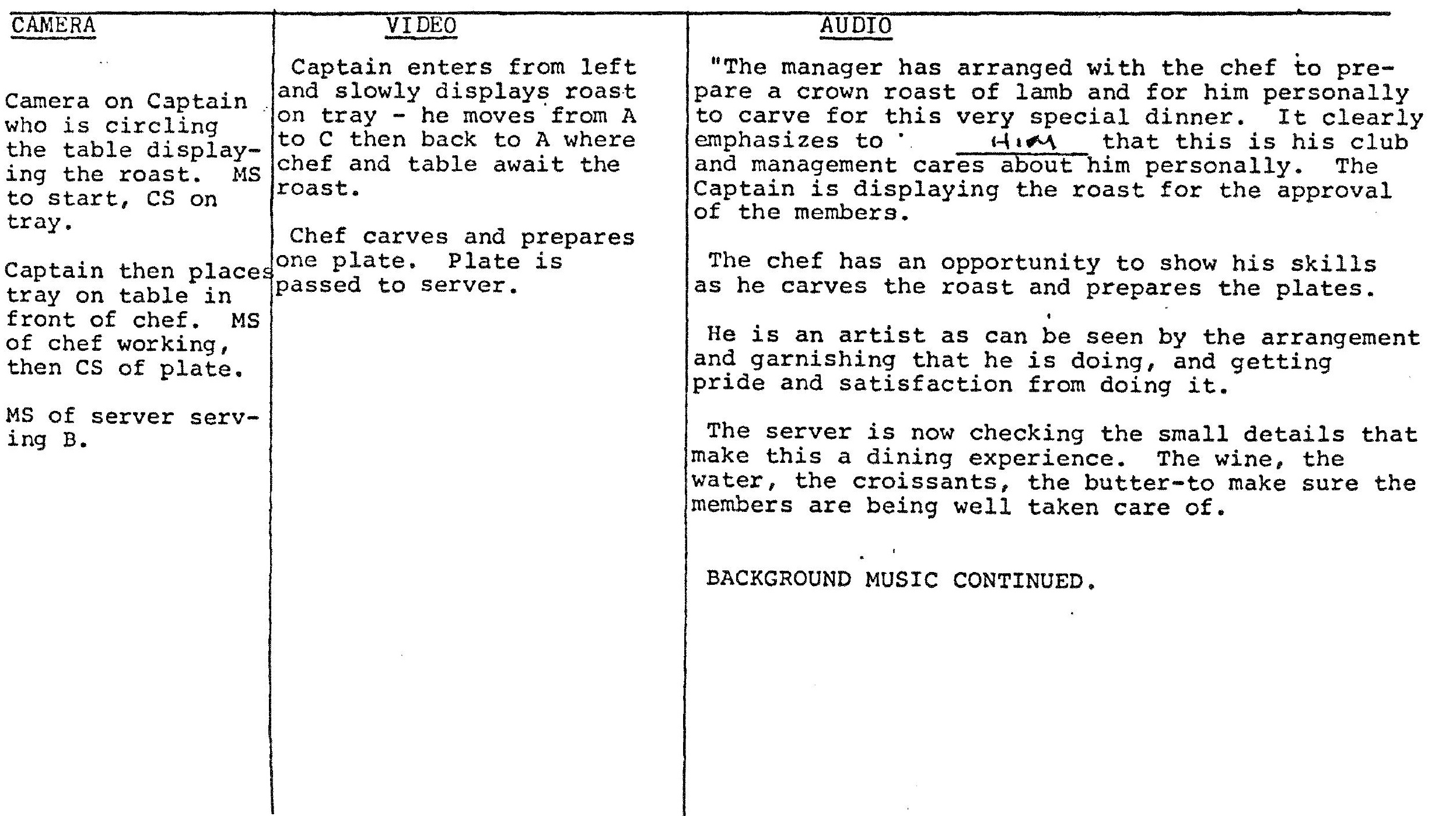


PRODUCTION SCRIPT

TITLE YCISYR
SCENE 11

NUMBER
DATE
MS of captain plating . a dessert from the pastry cart. Cart is diagonally behind A. Pan right to $C$. NS to show server removing last entree plate from table and placing on tray Pan to left as server approaches Captains cart. Follow back to table as desserts are placed befare guests.

\section{VIDEO}

Cart is positioned diagonally behind A with captain behind it. He has plated four pastries.

Server removes last plate from table, places it on the tray stand and approaches dessert cart.

The server places desserts around table. 2nd server enters from right and starts pouring coffee following 1 st. server.

\section{AUDIO}

\section{NARRATOR}

"The coffee is served using saucer as a shield so that the member can not get splashed! Just the little extra touch that is expected in our club."

\section{MUSIC}

Background music continued. 
DESIGN SHEET - SCRIPT/STORYBOARD

PAGE\# OF

\section{PRODUCTION SCRIPT}

TITIE YCISYR
SCENE 12

NUMBER
DATE

$\frac{\text { CAMERA }}{\text { Zoom in CS }}$
on Cordial cart.
Server is positioned
it between A\&D.
Zoom back to $M S$
$t$ include server.

\begin{abstract}
VIDEO
Cordials are visable before $A, B, \& C$. Server is pouring cordial at cart for $D$ and serves it on an underliner.

2nd server approaches from right with coffee pot and is smilingly waved away.
\end{abstract}

Actors very relaxed.

\section{AUDIO}

\section{NARRATOR}

Dining at our club is a complete event. The care, professional pride and interest of our employees is clearly shown.

\section{MUSIC}

Background music continued. 
DESIGN SHEET - SCRIPT/STORYBOARD

PAGE\# OF

PRODUCTION SCRIPT

TITLE YCISYR
SCENE 13

NUMBER
DATE

\section{CAMERA}

MS of table

\#1. Action

will be on A\&B.

\section{VIDEO}

Captain places checks on tray (or in folder) on the right of $A$.

A signs check while captain moves to assist $B$, holding chair.

\section{AUDIO}

NARRATOR

"Our club considers the parting procedure an important part of the dining room service.

The check is presented promptly but the member is never hurried to sign it.

Courtesies are always extended both on entrance and exit."

\section{MUSIC}

Background music continues. 

$O F$

PRODUCTION SCRIPT

PITLE YCISYR
SCENE

NUMBER
14

DATE

\section{AUDI0}

\section{NARRATION}

on his pad. He addresses guests and they order appetizers, salad, and dinner.

After taking order captain hands member wine list.

Captain "Are you ready to Order? As an appetizer tonight we have fresh Oysters on the half shell.

B LADY "I Mll have, a shrimp cocktail"

D LADY "A fruit cup".

A MAN "I'll have the oysters."

C $\underline{\text { MAN }}$ "The strawberries Dubonnet".

Captain "Thank-you. Our special salad.

is the Westview In addition to our regular menu we have Fresh Snapper Caprice. This is sauted in butter with banana slices.

LADY B "I'11 have the snapper".

LADY D "I'll have the roast beef"

Captain "How would you like it prepared?"

LADY D "Medium rare, please".

May A" "I' 11 have the roast beef, rare, please". MAN C: "I'Ii have the snapper".

- Captain "Would you like to see a wine list?" 


\section{DESIGN SHEET - SCRIPT/STORYBOARD}

SCENE 14

PRODUCTION SCRIPT

TITLE YCISYR
NUMBER
PAGE\# OF

DATE
CAMERA

MS OF TABLE. CLOSE UD OE A $\operatorname{sA}(4), A N D$ EAcit COURSE
VIDEO

\section{AUDIO}

CAPTAIN "Last time your were here you ordered our Chocolate souffle". Would you care for this as your dessert tonight?

I should alert the kitchen now if you do. Because it take 45 minutes to prepare.

MAN C "Yes let's have one and put it on my check".

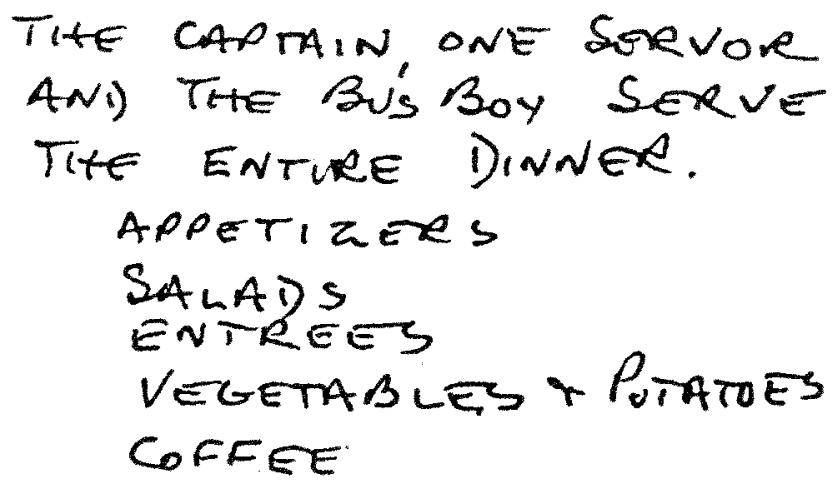




\section{DESIGN SHEET - SCRIPT/STORYBOARD}

SCENE 15

PRODUCTION SCRIPT

TITIE YCISYR
NUMBER

DATE

\begin{tabular}{lll}
\multicolumn{1}{c}{ CAMERA } & VIDEO & AUDIO \\
MS of souffle & 2 servers from leff with & NARRATOR \\
on tray. Zoom & 2 trays. Souffle and plates on & "The meal is climaxed by this beautiful \\
in to show it & on tray, whipped cream and & unusual dessert, that says at our club, \\
being plated. & chocolate on other. Souffle & we care. Our club is noted for its specials \\
Camera straight on. & is displayed to members, & and this is recomnended for all clubs. \\
Follow servers & moving from A to C and back & \\
to first two guests. & to A. Souffle is placed and tray & \\
& stand and plates are prepared. & The members pay for and expect some things \\
& Server \#l serves, Server $\# 2$ & different and they get it here. \\
& Serves chocolate and whipped &
\end{tabular}

None 


\section{DESIGN SHEET - SCRIPT/STORYBOARD}

\section{PRODUCTION SCRIPT}

TITIE YCISYR
SCENE 16

NUMBER
PACE\# OF

DATE

\section{CAMERA}

MS of meetings.

\section{VIDEO}

Tne Manager, Chef and Maitre d' are seated at a table

The Maitre d' have the staff. lined up at the rear of the dining room.

\section{AUDIO}

\section{NARRATOR}

The success of our club begins on planning, training and the working relationship of the staff. The communication media used by the Manager is meeting.

We see the Manager meeting with his chef and 'Maitre d' to discuss a new menu item.

The second meeting is between the Maitre d' his Captains and service staff to do two very important things:

1. To inspect them to see that they are properly uniformed and personable, and

2. To discuss the days menu. 

OF

PRODUCTION SCRIPT

TITLE YCISYR
SCENE 20

NUMBER
DATE

\section{CAMERA}

Ise dining room

icene.

\section{VIDEO}

Use film from dining

room mob scene.
THE END

CREDITS

\section{AUDIO}

NARRATOR

The object of this film is to stimulate interest in $y$ raising dining room standards. And to illustrate that clubs do serve you right!

Thanks to the talented Florida International University, School of Hospitality Management students of the Sunblazer Chapter who assisted Ted white, Professor at the University in writing producing and directing this project.

A special thanks to Don Sheehy, General Manager of Westview Country CIub and its members who graciously provided the use of their beautiful club during the filming. 
A PPENDIX C 


\section{APAPISIXC \\ South Florida Seminole Chapter}

Written Examination Accompanying Training Film

"Your Club It Serves You Right"

1. The first rule for success in any venture is inspection

by the captain for table setup and cleanliness of each table.

True

False

2. The two types of service depicted in the film are

TRADITIONAL FRENCH with minor variations and AMERICAN CLUB STYLE SERVICES.

True

False

3. The seven steps of proper wine service are:

(1) Show the host the label

(2) Open the bottle

(3) Give the cork to the host

(4) Give host tasting

True

4. It is not necessary to remove the water glass from the table while pouring.

True

False

5. Coffee cups are not to be removed from the table when pouring coffee.

- True

False

6. Soups, salads, and entrees are served to the guests' left.

True

False

7. Water, coffee and other liquids are served to the guests' right.

True

False

8. Vegetables are served to the guests' right. 
9. The service plate is removed from under the soup dish before serving the soup.

True

False

10. Serving rolls separetely is economically wise and provides a special touch to service.

True

False

11. The key to success of any club's dining program is planning, training, and developing a good working relationship between managers and staff.

True

False 
A PPENDIX D 


\section{FLORIDA INTERNATIONAL UNIVERSITY}

TAMIAMI CAMPUS * MIAMI, FLORIDA $33199 \cdot(305) 554.2591$

HOSPITALITY MANAGEMENT

Mr. Charles E. Smith, CCM

Club Manarers Association of America

7615 Winterberry Place

P.O. Box 34482

Bethesda, Maryland 20817

Dear Mr. Smith:

Attached as an inclosure to this letter is a study done by one of our graduate students, Terry Clark, on the subject of video-taped training films relating specifically to club management. The end product of this study is a video tape and supplementary written exam covering the proper serving techniques of Wine Service, French Style Service and "American Club Style Service" (Inclosed).

The idea behind this study is:

(1) There currently are no training films produced unique to club management.

(2) A CMAA Library could be established at National Headquarters by student chapters producing a new film each year under the auspices of the IRP Committee.

(3) That funds operated from the sale of these video tapes will help offset travel and lodginr expenses to local, regional and national CMAA Conferences for student members of the University producing a film. follows:

The mechanics of how we see this being handled are as

(1) The film. masters w111 be provided CMAA National Headquarters.

(2) CMAA National Headquarters will market and advertise the availability of the film.

(3) Orders received by CMAA National Headquarters will be filled by CMAA National Headquarters in cooperation with a duplicating company in the Washington, D.C. area. 


\section{FLORIDA INTERNATIONAL UNIVERSITY}

TAMIAMI CAMPUS. MIAMI. FLOAIDA $33199 \cdot$ ( 305 ) 554.2591

HOSPITALITY MANAGEMENT

(4) Sellinp price of the film will be $\$ 100.00$.

(5) Profits from the sale of the film will be divided equally between CMAA, the South Florida Seminole Chapter, and the Florida International University Foundation, Hospitality School (CMAA) Accounts, and distributed on a quarterly basis.

Please advise as to your consideration of this proposal so we can "get the ball rolling."

Sincerely,

TED WHITE

Cc: Raymond $D$. Watts, CCM

James E. Petzing, CCM

James $\mathrm{H}$. Brewer, CCM

Walker M. Brown, CCM

Don Sheehy

Gene Marshall 
SELECTED BIBLIOGRA PHY

Books

Lundberg, Donald E. and Armatas, James P. The Management of People in Hotels, Restaurants and clubs. 3d Edition, Dubuque, Iowa, William C. Brown Co., 1974.

White, Ted. Club onerations and Management. Boston, Mass.: CBI Publishing Company, Inc., 1979.

Articles

Author Unknown. "Training: The Only Way to Fly." Hospitality, July, 1975.

Author Unknown. "OOJ 30 Skill Qualification Test to Begin in June." Army Host, April-May 1980.

Author Unknown. "Films and Videotapes." Army Host, September/ October 1981.

Hayes, James I. "Effective Training." Personnel Journal. August 1974.

"How to Make Smart Video Connections." Pamphlet by Xantech Corporation, 1982.

McNerney, Chris. "CHAPT explores Total Training Approach." Institutions/Volume Feeding. June 1, 1976.

Miller, Eldon. "Training the Opening, Crew." Restaurant Business. May 1978.

NEM Inc., 1982 Catalog, National Educational Media, Inc.

Oliva, Lucy. "3-Phase Program Puts Teeth and ICM into OOJ Training." Army Host, April/May 1980.

"The Chapter Achievement Award for Student Chapters." CMAA Pamphlet, 1982-1983.

The 1983 CMAA Student Chapter Handbook (CMAA National HQ, Bethesda Maryland.).

Valley, Frank C. "A CM Survey of Students." Club Management. February 1983. 
Wulff, Peter. "Training Program" You're Kidding." Club Management. December, 1976.

1982-1983 Yearbook, CMAA National HQ, Bethesda, Maryland 20817. 


\section{VITA}

\section{SHELBY TERRY CLARK}

Shelby "Terry" Clark was born in New York City, July 28, 1945, but was raised on a farm in Southern IIIinois where his interests included music, religion and sports. After sevezal college major changes from music to psychology to business, he entered the Army in 1968 as a private. Enlisted service (advancing to the rank of staff sergeant) of four years consisted primarily of administrative duties in Vietnam and Germany. Following completion of Infantry officers Candidate School, he spent several years in airborne combat units and later as an aide for a general officer (four years). He entered the field of club management in 1977. Captain Clark recently received his tenth U.S. Army selection for promotion to major and will become the Installation Club Manager at Fort Monroe, Virginia in May, 1983.

He has been married to Cynthia Laver Clark (Erie, Pennsylvania) for fourteen years and has two boys, Brady Ryan and Tyler Newton. 